\title{
Convenient Synthesis, Characterization, Cytotoxicity and Toxicity of Pyrazole Derivatives
}

\author{
Mona M. Kamel \\ Pharmaceutical Organic Chemistry Department, Faculty of Pharmacy, Cairo University, 11562, Cairo, Egypt \\ *Corresponding author: E-mail: mona_mounir50@ hotmail.com
}

Received: 16-07-2014

\begin{abstract}
3-Methyl-1 $H$-pyrazol-5(4H)-one (1) was used as a template to develop new anticancer compounds and investigate their SAR. The ring modification of compound $\mathbf{1}$ occurred through its reaction with aromatic aldehydes and various reagents to afford the corresponding 6-oxopyrano[2,3-c]pyrazoles $\mathbf{4 a - c}$ and their amino analogues 6-aminopyrano[2,3-c]pyrazoles $\mathbf{6 a}-\mathbf{c}, \mathbf{8}$; the pyrazolopyrano[2,3-b]pyridines 10a-c and the chromenopyrano[2,3-c]pyrazolones 13,14. The reaction of $\mathbf{1}$ with thiourea and appropriate aromatic aldehydes afforded the pyrazolo[3,4- $d]$ pyrimidine derivatives 17a-c. On the other hand, the pyrazolo[3,4- $d$ ] thiazole derivatives $\mathbf{2 2 a}-\mathbf{d}$ were obtained via the reaction of $\mathbf{1}$ with sulfur and aryl isothiocyanates in the presence of triethylamine. The reaction of $\mathbf{1}$ with phenylisothiocyanate followed by treatment with the $\alpha$-halocarbonyl compounds $24 \mathbf{a}-\mathbf{c}$ afforded the thiazole derivatives $\mathbf{2 5 a}-\mathbf{c}$. The synthesized products were evaluated for their cytotoxicity against cancer and normal cell lines. Most compounds showed significant anticancer activity without affecting the normal fibroblast cells. The toxicity of the most pontent cytotoxic compounds was measured using Brine-Shrimp Lethality Assay.
\end{abstract}

Keywords: Pyrazole; pyrano[2,3-c]pyrazole; pyrazolo[3,4- $d]$ pyrimidine; pyrazolo[3,4- $d]$ thiazole; cytotoxicity

\section{Introduction}

Cancer is a major public health problem in the world. Chemotherapy is still one of the primary modalities for the treatment of cancer. However, the use of this method is limited mainly due to the small number of the available chemotherapeutic agents to choose among them and also because the use of these agents is often accompanied by undesirable side effects. This clearly underlies the urgent need for developing novel chemotherapeutic agents with more potent antitumor activities and reduced side effects. Many pyrazole derivatives have attracted considerable attention in the recent years for their diverse biological activities. ${ }^{1-6}$ They are also acknowledged for their anticancer activities. ${ }^{7-9}$ Celecoxib, sulfaphenazole, CDPPB, linazolac, mepiprazole, and rimonabant are some of the pyrazole-based drugs available today in the market (Figure 1). ${ }^{10}$

Moreover, the chemistry of fused pyrazole derivatives has received great attention due to their pharmacological importance. ${ }^{11,12}$ It has been found that pyranopyrazoles are an important class of biologically active heterocycles. They are reported to possess a multiplicity of pharma- cological properties including anticancer, ${ }^{13}$ antimicrobial, ${ }^{14}$ anti-inflammatory, ${ }^{15}$ insecticidal and molluscicidal activities. ${ }^{16,17}$ They are also potential inhibitors of human Chk1 kinase. ${ }^{18}$ On the other hand, pyrazolopyrimidines which are the fused heterocyclic ring systems that structurally resemble purines, prompted biological investigations to assess their potential therapeutic significance. They are known to play a crucial role in numerous disease conditions. The collective results of biochemical and biophysical properties foregrounded their medicinal significance in central nervous system, cardiovascular system, cancer and inflammation. ${ }^{19-21}$ In addition, several 1,3-thiazole scaffolds have been reported as potent anticancer agents. ${ }^{22-24}$ The synthesis of some new pyrazole-based 1,3-thiazoles as anticancer agents was reported. ${ }^{25}$ Most recently, excellent anticancer effectiveness of pyrazolylthiazole derivatives was also reported, via EGFR TK inhibition that plays an important role in cell growth regulation. ${ }^{26}$ However, according to the literature and to our knowledge, the discovery of the potential anticancer activity of pyrazolothiazoles is still essentially in the development stage. In view of the aforementioned facts, our efforts were directed towards the uses of 3-methyl- $1 H$-pyra- 

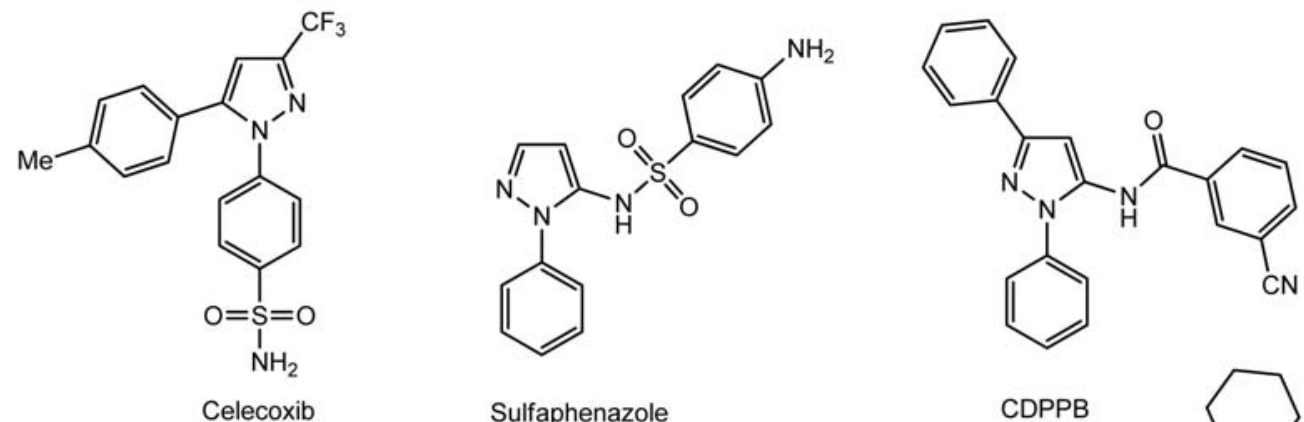
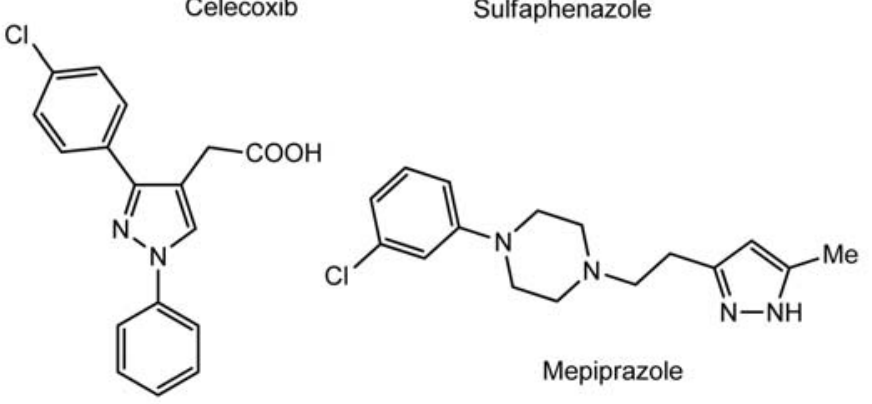

Mepiprazole

Lonazolac

Sulfaphenazole

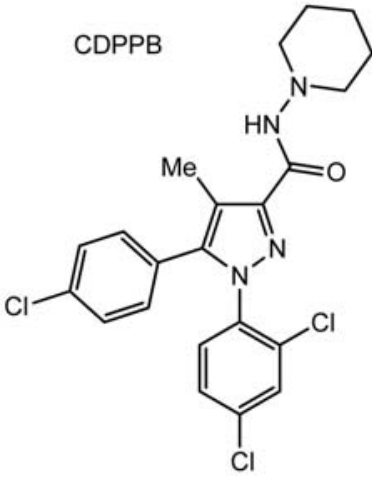

Rimonabant

Figure 1. Biologically active pyrazole derivatives.

zol-5(4H)-one to prepare heterocyclic and fused derivatives together with evaluation of their activity towards cancer and normal cell lines.

\section{Results and Discussion}

\section{1. Chemistry}

The present investigation mainly on the synthesis of molecules derived from pyrazole-5-one and evaluation of their cytotoxicity against cancer and normal cell lines. The synthetic strategies adopted for the synthesis of the intermediate and target compounds are depicted in Schemes 1-4. One pot multicomponent reactions (MCR) were utilized to prepare the target compounds. The reaction of the 3-methyl-1H-pyrazol-5(4H)-one (1) with each of benzaldehyde (2a), 4-methoxybenzaldehyde (2b) or 4-chlorobenzaldehyde (2c) and ethyl cyanoacetate (3) afforded the 6-oxopyranopyrazole derivatives $\mathbf{4 a - c}$. The structure of the latter products was confirmed on the basis of their respective analytical and spectral data. Thus, ${ }^{1} \mathrm{H}$ NMR spectrum of 4 a revealed the presence of a singlet at $\delta 2.49$ ppm indicating the presence of the $\mathrm{CH}_{3}$ group, a multiplet at $\delta 7.59-8.41 \mathrm{ppm}$ equivalent to the $\mathrm{C}_{6} \mathrm{H}_{5}$ group and a singlet at $\delta 10.40 \mathrm{ppm}$ corresponding to the $\mathrm{NH}$ group. Moreover the ${ }^{13} \mathrm{C}$ NMR spectrum demonstrated a signal at $\delta 14.1$ equivalent to the $\mathrm{CH}_{3}$ group, $\delta 116.0$ corresponding to the $\mathrm{CN}$ group, signals at $\delta 128.6,129.5,129.7,129.8$, $131.3,131.8,133.0,133.9$ corresponding to the phenyl, pyran and pyrazole carbons and a signal at $\delta 155.7$ corres- ponding to $\mathrm{C}=\mathrm{O}$. Meanwhile, the reaction of $\mathbf{1}$ with either of $\mathbf{2 a}, \mathbf{2 b}$ or $\mathbf{2 c}$ and malononitrile (5) in ethanol containing triethylamine gave the 6-amino-3-methyl-4-aryl-1,4-dihydropyrano[2,3-c]pyrazole-5-carbonitrile derivatives $\mathbf{6 a - c}$, respectively. The analytical and spectral data of $\mathbf{6 a - c}$ were in consistence with their respective structures. The latter compounds were previously reported to be prepared via a one pot, four component reaction between aldehydes, hydrazine hydrate, malononitrile and ethyl acetoacetate in the presence of different catalysts. ${ }^{27}$ On the other hand, the reaction of compound 1 with pyridine-3-aldehyde (7) and malononitrile (5) afforded the 6-amino-3methyl-4-(pyridin-3-yl)-1,4-dihydropyrano[2,3-c]pyrazole-5-carbonitrile (8). The structure of the latter product was based on its respective analytical and spectral data. Thus, the ${ }^{1} \mathrm{H}$ NMR spectrum showed the presence of a singlet at $\delta 1.79 \mathrm{ppm}$ indicating the $\mathrm{CH}_{3}$ group, a singlet at $\delta 4.69$ ppm equivalent to the pyran $\mathrm{H}-4$, a singlet at $\delta 6.95$ ppm for the $\mathrm{NH}_{2}$ group and a multiplet at $\delta 7.32-8.46 \mathrm{ppm}$ corresponding to the pyridine protons.

Moreover, the reaction of $\mathbf{1}$ with the aromatic aldehydes 2a-c and 2-aminoprop-1-ene-1,1,3-tricarbonitrile (9) in ethanol containing a catalytic amount of triethylamine afforded the pyrazolopyrano[2,3- $b]$ pyridine-6-carbonitrile derivatives 10a-c. ${ }^{1} \mathrm{H}$ NMR of $\mathbf{1 0 a}$ (as an example) showed the presence of a singlet at $\delta 2.49 \mathrm{ppm}$ corresponding to the $\mathrm{CH}_{3}$ group, a singlet at $\delta 4.58 \mathrm{ppm}$ for the pyran $\mathrm{H}-4$, two singlets at $\delta 7.10$ and $8.02 \mathrm{ppm}$ indicating the presence of the two $\mathrm{NH}_{2}$ group. Moreover, ${ }^{13} \mathrm{C} \mathrm{NMR}$ showed signals at $\delta 36.9$ indicating the pyran C-4 and signals at $\delta 114.1,127.1,128.3,129.1,137.3,144.9,146.8$, 
$148.4,150.6,154.3,154.0$ equivalent to the phenyl, pyrazole, pyran and pyridine carbons. On the other hand, the reaction of the compound $\mathbf{6 b}$ with phenylisothiocyanate (11) in 1,4-dioxane afforded the corresponding thiourea derivative 12, the structure of which was based on analytical and spectral data.
The one-pot reaction of compound $\mathbf{1}$ with salicylaldehyde and malononitrile gave the annulated 5-amino-1methyl-3H-chromeno[4',3':4,5]-pyrano[2,3-c]pyrazol$6(11 \mathrm{bH})$-one (13). The analytical and spectral data of the latter product was the basis of its structural elucidation. Thus, the ${ }^{1} \mathrm{H}$ NMR spectrum of $\mathbf{1 3}$ showed, beside the ex-
$\mathrm{H}_{3} \mathrm{C}$<smiles>CC1=NNC(=O)C1</smiles>

1<smiles>[X]c1ccc(C=O)cc1</smiles>

2a, $\mathrm{X}=\mathrm{H}$

b, $\mathrm{X}=\mathrm{OCH}_{3}$

c, $\mathrm{X}=\mathrm{Cl}$ (a)<smiles>[X]c1ccc(-c2c(C#N)c(=O)oc3[nH]nc(C)c23)cc1</smiles>
4a, $\mathrm{X}=\mathrm{H}$
b, $\mathrm{X}=\mathrm{OCH}_{3}$
c, $\mathrm{X}=\mathrm{Cl}$

(b)<smiles>[X]c1ccc(C2C(C#N)=C(N)Oc3[nH]nc(C)c32)cc1</smiles>

6a, $\mathrm{X}=\mathrm{H}$

b, $\mathrm{X}=\mathrm{OCH}_{3}$

c, $\mathrm{X}=\mathrm{Cl}$

b, $\mathrm{X}=\mathrm{OCH}_{3}$

c, $\mathrm{X}=\mathrm{Cl}$<smiles>CC1=NNC(=[OH+])C1</smiles><smiles>O=Cc1cccnc1</smiles><smiles>N#CCC#N</smiles>

(c)<smiles>Cc1n[nH]c2c1C(c1cccnc1)C(C#N)=C(N)O2</smiles>

7

5

8<smiles>CC1=NNC(=[OH+])C1</smiles><smiles>[X]c1ccc(C=O)cc1</smiles><smiles>N#CC(C#N)=C(N)CC#[N+]</smiles>

(d)

1
2a, $\mathrm{X}=\mathrm{H}$
b, $\mathrm{X}=\mathrm{OCH}_{3}$

9

c, $\mathrm{X}=\mathrm{Cl}$<smiles>[X]c1ccc(C2c3c(C)n[nH]c3Oc3nc(N)c(C#N)c(N)c32)cc1</smiles>
10a, $\mathrm{X}=\mathrm{H}$
b, $\mathrm{X}=\mathrm{OCH}_{3}$
c, $\mathrm{X}=\mathrm{Cl}$

Scheme 1. Synthesis of pyrazole derivatives $4 \mathbf{a}-\mathbf{c}, \mathbf{6 a}-\mathbf{c}, \mathbf{8}$ and $\mathbf{1 0 a}-\mathbf{c}$; reagents and conditions: (a) EtOH/Et ${ }_{3} \mathrm{~N}$, heat $1 \mathrm{~h} ;\left(\right.$ b) $\mathrm{EtOH} / \mathrm{Et}_{3} \mathrm{~N}$, heat $1 \mathrm{~h}$; (c) $\mathrm{EtOH} / \mathrm{Et}_{3} \mathrm{~N}$, heat $2 \mathrm{~h}$; (d) $\mathrm{EtOH} / \mathrm{Et}_{3} \mathrm{~N}$, heat $1 \mathrm{~h}$. 
pected signals, the presence of a singlet at $\delta 4.14 \mathrm{ppm}$ indicating the $\mathrm{NH}_{2}$ group, a multiplet at $\delta 7.29-7.57 \mathrm{ppm}$ corresponding to the $\mathrm{C}_{6} \mathrm{H}_{4}$ group and a singlet at $\delta 11.01$ ppm $\left(\mathrm{D}_{2} \mathrm{O}\right.$ exchangeable $)$ for the $\mathrm{NH}$ group. Moreover, the ${ }^{13} \mathrm{C}$ NMR spectrum showed $\delta 162.0,162.5,163.0$ indicating the $\mathrm{C}=\mathrm{N}$ and $\mathrm{C}=\mathrm{O}$ groups. Similarly, the reaction of compound 1 with salicylaldehyde and ethyl cyanoacetate (3) furnished the 1-methyl-3H-chromeno[4',3':4,5]pyrano[2,3-c]pyrazole-5,6-dione (14).

The multi-component reaction (MCR) of compound 1 with thiourea and aromatic aldehydes was investigated. Thus, the one-pot reaction of the pyrazole 1 with thiourea<smiles>COc1ccc(C2C(C#N)=C(N)Oc3[nH]nc(C)c32)cc1</smiles>

$+\quad$ PhNCS

11<smiles>COc1ccc(C2C(C#N)=C(Nc3ccccc3)Oc3[nH]nc(C)c32)cc1</smiles>

12

6b<smiles>CC1=NNC(=[OH+])C1</smiles>

1<smiles>N#CCC#N</smiles><smiles>O=Cc1ccccc1O</smiles>

(b)

(a)<smiles>CCCC</smiles>
5<smiles>Cc1n[nH]c2c1C1C(=C(N)O2)C(=O)Oc2ccccc21</smiles>

13<smiles>Cc1n[nH]c2oc(=O)c3c(=O)oc4ccccc4c3c12</smiles>

1 3

(c)<smiles>O=Cc1ccccc1O</smiles><smiles>C=C[CH2-]</smiles>

(d)<smiles>CC1=NNC(=[OH+])C1</smiles>

1<smiles>NC(N)=S</smiles>

15<smiles>[X]c1ccc(C=O)cc1</smiles>

2a, $X=H$

b, $\mathrm{X}=\mathrm{OCH}_{3}$

16, $\mathrm{X}=\mathrm{Br}$
14<smiles>[X]c1ccc(-c2nc(=S)[nH]c3[nH]nc(C)c23)cc1</smiles>

17a, $\mathrm{X}=\mathrm{H}$

b, $\mathrm{X}=\mathrm{OCH}_{3}$

c, $\mathrm{X}=\mathrm{Br}$

Scheme 2. Synthesis of pyrazole derivatives 12-14 and 17a-c; reagents and conditions: (a) 1,4-dioxane/Et 3 , heat $2 \mathrm{~h}$; (b) EtOH/Et $3 \mathrm{~N}$, heat $2 \mathrm{~h}$; (c) $\mathrm{EtOH} / \mathrm{Et}_{3} \mathrm{~N}$, heat $2 \mathrm{~h}$; (d) $\mathrm{EtOH}_{2} / \mathrm{Et}_{3} \mathrm{~N}$, heat $1 \mathrm{~h}$. 
(15) and either benzaldehyde (2a), 4-methoxybenzaldehyde $(\mathbf{2 b})$ or 4-bromobenzaldehyde (16) in the presence of triethylamine gave the pyrazolo[3,4- $d]$ pyrimidine derivatives 17a-c. The structure of the synthesized compounds was confirmed via the analytical and spectral data (see experimental section).

Reaction of compound $\mathbf{1}$ with triethylorthoformate (18) in an oil bath at $120^{\circ} \mathrm{C}$ afforded the 4-(ethoxymethylene)-3-methyl-1H-pyrazol-5(4H)-one (19). The structure of 19 was established on the basis of analytical and spectral data. Thus, the ${ }^{1} \mathrm{H}$ NMR spectrum showed a triplet and quartet at $\delta 1.29$ and $4.15 \mathrm{ppm}$ corresponding to the ethyl group and a singlet at $\delta 7.38 \mathrm{ppm}$ indicating $\mathrm{CH}=\mathrm{C}$ group. Meanwhile, the reaction of $\mathbf{1}$ with malononitrile and triethylorthoformate in ethanol afforded $\mathbf{2 0}$. The presence of the two $\mathrm{CN}$ groups was indicated by the presence of two absorption bands in the IR spectrum at $v 2204$, $2179 \mathrm{~cm}^{-1}$, respectively. ${ }^{1} \mathrm{H}$ NMR spectrum showed a sin-<smiles>CC1=NNC(=O)C1</smiles>

1
$(\mathrm{EtO})_{3} \mathrm{CH}$

18 glet at $\delta 8.66 \mathrm{ppm}$ corresponding to the $\mathrm{CH}=\mathrm{C}$ group. Further confirmation of the structure of compound $\mathbf{2 0}$ was obtained through its synthesis via another reaction route. Thus, the reaction of malononitrile (5) with $\mathbf{1 9}$ gave the same product 20 (m.p. and mixed m.p. and finger print IR). Moreover, the reaction of compound 1 with elemental sulfur and either phenylisothiocyanate (11), 4-methoxyphenylisothiocyanate (21a), 4-chlorophenylisothiocyanate (21b), or 4-bromophenylisothiocyanate (21c) in 1,4-dioxane containing triethylamine gave the pyrazolo[3,4$d$ thiazole derivatives 22a-d. The structure of the latter products was based on the analytical and spectral data. Thus, the ${ }^{1} \mathrm{H}$ NMR spectrum of $\mathbf{2 2 a}$ (as an example) showed the presence of a singlet at $\delta 2.49 \mathrm{ppm}$ corresponding to $\mathrm{CH}_{3}$ group, a mutiplet at $\delta 7.09-7.50 \mathrm{ppm}$ corresponding to the phenyl protons and a singlet at $\delta 9.75$ equivalent to the $\mathrm{NH}$ group. Moreover, the ${ }^{13} \mathrm{C}$ NMR spectrum showed the presence of the $\mathrm{CH}_{3}$ group at $\delta 12.27$, the (a)<smiles>CCOC=C1C(=O)NN=C1C</smiles>

19<smiles>CC1=NNC(=O)C1</smiles>

1<smiles>CCOCCOCCC#N</smiles>

18

5 (b)<smiles>CC1=NNC(=O)C1=CC(N)C#N</smiles><smiles>[CH-][O+]=C1CC(C)=NN1</smiles>

1<smiles>[X]c1ccc(NS(C)(=O)=O)cc1</smiles>

Scheme 3. Synthesis of pyrazole derivatives 19, 20, 22a-d; reagents and conditions: (a) fusion $120{ }^{\circ} \mathrm{C}, 30 \mathrm{~min}$; (b) EtOH/Et ${ }_{3} \mathrm{~N}$, heat 2 h; (c) 1,4-dioxane/ $\mathrm{Et}_{3} \mathrm{~N}$, heat $3 \mathrm{~h}$. 

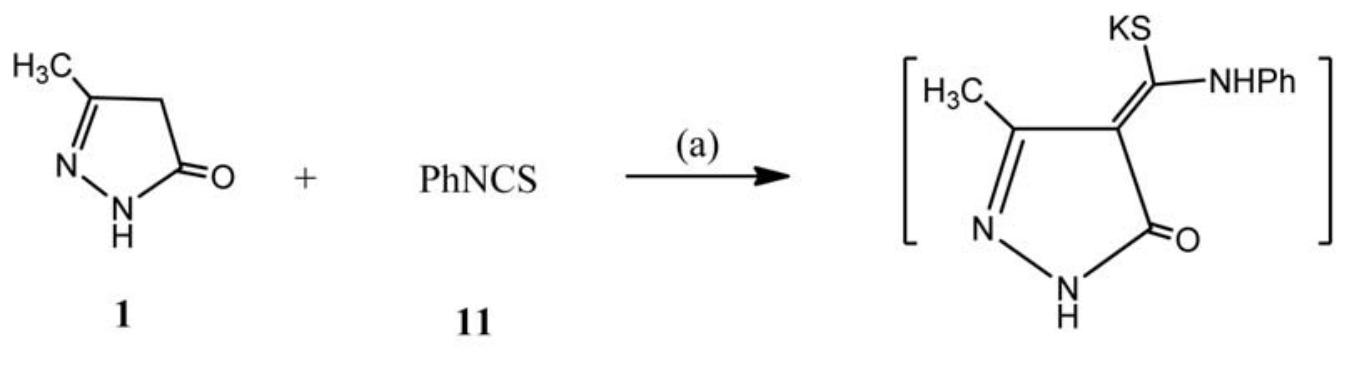

23

(b)
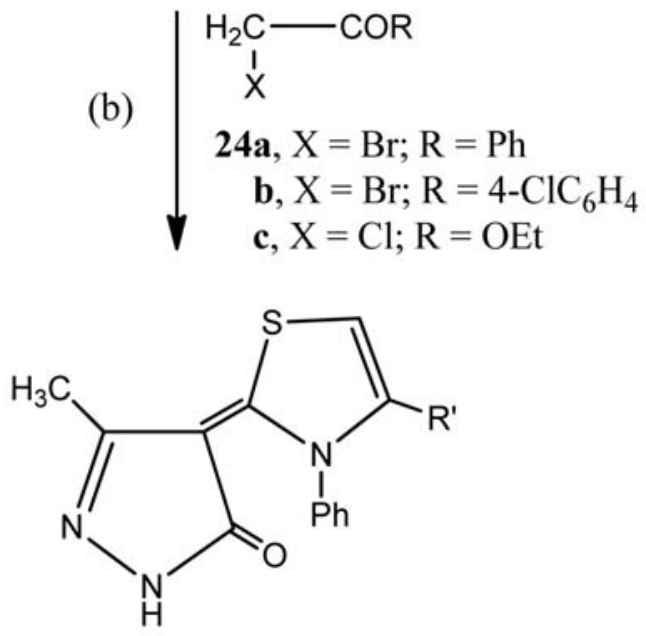

$$
\begin{aligned}
\text { 25a, } R^{\prime} & =\mathrm{Ph} \\
\text { b, } \mathrm{R}^{\prime} & =4-\mathrm{ClC}_{6} \mathrm{H}_{4} \\
\text { c, } \mathrm{R}^{\prime} & =\mathrm{OH}
\end{aligned}
$$

Scheme 4. Synthesis of pyrazole derivatives $\mathbf{2 5 a}-\mathbf{c}$; reagents and conditions: (a) DMF/KOH, r.t.; (b) r.t., overnight.

phenyl and pyrazole carbons at $\delta 124.5,128.5,128.9$, $129.4,130.4,137.8,139$ and the $\mathrm{C}=\mathrm{S}$ group at $\delta 180.1$.

The methylene group present in the pyrazole 1 was reported to show high reactivity towards thiazole formation via its reaction with phenylisothiocyanate in basic DMF solution followed by heterocyclization with $\alpha$-halocarbonyl compounds. ${ }^{28,29}$ Thus, $\mathbf{1}$ was reacted with phenylisothiocyanate in $\mathrm{DMF} / \mathrm{KOH}$ solution to give the intermediate potassium sulfide salt $\mathbf{2 3}$. The reaction of the latter intermediate with either 2-bromo-1-phenylethanone (24a), 2-bromo-1-(4-chlorophenyl)ethanone (24b) or ethyl chloroacetate $(\mathbf{2 4 c})$ gave the thiazole derivatives $\mathbf{2 5 a - c}$. The structures was of the latter products were established on the basis of their respective analytical and spectral data.

\section{2. In vitro Cytotoxicity}

\section{2. 1. Effect on the Growth of Human Cancer Cell Lines}

The heterocyclic compounds prepared in this study were evaluated according to standard protocols for their in vitro cytotoxicity against six human cancer cell lines inclu- ding cells derived from human gastric cancer (NUGC), human colon cancer (DLD1), human liver cancer (HA22T and HEPG2), nasopharyngeal carcinoma (HONE1), human breast cancer (MCF) and normal fibroblast cells (WI38). For comparison, CHS 828 was used as the standard anticancer drug. All of $\mathrm{IC}_{50}$ values in $(\mathrm{nM})$ are listed in Table 1 and the results are presented graphically in Figures 2-4. Many of the synthesized heterocyclic compounds were observed with significant cytotoxicity against most of the cancer cell lines tested $\left(\mathrm{IC}_{50}<1000 \mathrm{nM}\right)$. Normal fibroblasts cells (WI38) were affected to a much lesser extent $\left(\mathrm{IC}_{50}>10,000 \mathrm{nM}\right)$. Among the tested compounds the 3-methyl-6-phenyl- $1 H$-pyrazolo[3,4- $d$ ] thiazole-5(6H)thione (22a) was found to show the highest cytotoxic effect against the six cancer cell lines in the range of $\mathrm{IC}_{50} 33-442$ $\mathrm{nM}$. Broad spectrum antitumor activity was exhibited by compounds 4c, 6b, 10b, 12, 17b, 19, 22a, 22b and 22d. Several compounds showed potent cytotoxic effect with $\mathrm{IC}_{50}<100 \mathrm{nM}$, for example compounds: 8, 10c, 12, 22a, 22d against NUGC; 10b, 10c, 17b, 19, 20, 22a, 22b, 22d against DLD1; 6a, 17b, 19, 22a, 22d against HA22T, 17b against HEPG2 and 22a against MCF. 


\section{2. 2. Structure Activity Relationship}

In the present study, a series of heterocyclic derivatives incorporating a pyrazole moiety were synthesized and evaluated for their cytotoxicity aiming at investigating their SAR. Thus, 6-oxopyranopyrazoles $\mathbf{4 a - c}$ and their amino analogs $\mathbf{6 a - c}$ and $\mathbf{8}$ were prepared. Refering to the $\mathrm{IC}_{50}$ values listed in Table 1, 4a bearing a phenyl substituent exhibited significant broad spectrum cytotoxic activity in the range of $\mathrm{IC}_{50} 120-527 \mathrm{nM}$. Meanwhile, $4 \mathbf{b}$ bearing a 4- $\mathrm{OCH}_{3} \mathrm{C}_{6} \mathrm{H}_{4}$ group showed selective activity against liver cancer HEPG2 $\left(\mathrm{IC}_{50} 428 \mathrm{nM}\right)$ and breast cancer $\mathrm{MCF}\left(\mathrm{IC}_{50} 580 \mathrm{nM}\right)$. The $4-\mathrm{ClC}_{6} \mathrm{H}_{4}$ substituted derivative $\mathbf{4 c}$ demonstrated better activity compared to $\mathbf{4 a}$ and $4 b$ especially against gastric cancer NUGC $\left(\mathrm{IC}_{50} 60 \mathrm{nM}\right)$. Among the 6-amino-4-substituted pyranopyrazole derivatives $\mathbf{6 a}-\mathbf{c}$ and $\mathbf{8}$, derivative $\mathbf{6 a}$ carrying a phenyl group was found to have selective activity against the human liver cancer cell line HEPG2 $\left(\mathrm{IC}_{50} 399 \mathrm{nM}\right)$ and colon cancer cell line DLDI $\left(\mathrm{IC}_{50} 890 \mathrm{nM}\right)$. However, $6 \mathbf{b}$ bearing 4$\mathrm{OCH}_{3} \mathrm{C}_{6} \mathrm{H}_{4}$ group was completely devoid of cytotoxic activity. On the other hand, $\mathbf{6 c}$ bearing the $4-\mathrm{ClC}_{6} \mathrm{H}_{4}$ moiety showed high activity against all cancer cell lines except breast cell line MCF in the range of $\mathrm{IC}_{50} 120-359 \mathrm{nM}$. The presence of pyridine ring in $\mathbf{8}$ is most probably res- ponsible for its high potency against human liver cancer cell line HA22T $\left(\mathrm{IC}_{50} 58 \mathrm{nM}\right)$ and nasopharyngeal cancer cell line HONE1 ( $\left.\mathrm{IC}_{50} 180 \mathrm{nM}\right)$. The previous result suggests that the replacement of the 6-amino group in compounds $\mathbf{6 a - c}$ by a 6-oxo group in compounds $\mathbf{4 a - c}$ in the latter pyranopyrazole derivatives leads to compounds with enhanced cytotoxic effect which might be attributed to the presence of the electronegative oxygen moiety. Meanwhile, replacement of the 2-amino group in $\mathbf{6 b}$ by a phenylthiourea moiety afforded $\mathbf{1 2}$ which demonstrated a dramatic increase in the cytotoxic activity with the highest activity exhibited against NUGC ( $\left.\mathrm{IC}_{50} 36 \mathrm{nM}\right)$.

The investigation of the cytotoxicity of the pyrazolo[4',3':5,6]pyrano[2,3- $b$ ]pyridine derivatives $\mathbf{1 0 a}-\mathbf{c}$ revealed that 10a bearing a phenyl group exhibited selective activity against $\mathrm{MCF}\left(\mathrm{IC}_{50} 112 \mathrm{nM}\right)$. On the other hand, 10 bearing the 4- $\mathrm{OCH}_{3} \mathrm{C}_{6} \mathrm{H}_{4}$ group was found to be active against most cancer cell lines with the highest activity against NUGC $\left(\mathrm{IC}_{50} 122 \mathrm{nM}\right)$ and DLDI $\left(\mathrm{IC}_{50} 90 \mathrm{nM}\right)$. The 4- $\mathrm{ClC}_{6} \mathrm{H}_{4}$ substituted derivative $\mathbf{1 0 c}$ showed high cytotoxic activity against four cancer cell lines with potent activity against NUGC $\left(\mathrm{IC}_{50} 40 \mathrm{nM}\right)$ and DLDI $\left(\mathrm{IC}_{50} 60 \mathrm{nM}\right)$. Meanwhile, the tetracyclic chromenopyranopyrazoles $\mathbf{1 3}$ and 14 were found to be almost devoid of cytotoxic acti-

Table1. Cytotoxicity of the synthesized compounds against a variety of cancer cell lines ${ }^{\mathrm{a}}\left[\mathrm{IC}_{50}{ }^{\mathrm{b}}(\mathrm{nM})\right]$.

\begin{tabular}{|c|c|c|c|c|c|c|c|}
\hline \multirow[b]{2}{*}{ Compd } & \multicolumn{7}{|c|}{ Cytotoxocity $\left(\mathrm{IC}_{50}\right.$ in $\left.\mathrm{nM}\right)$} \\
\hline & NUGC & DLDI & HA22T & HEPG 2 & HONE1 & MCF & WI38 \\
\hline $4 \mathbf{4 a}$ & 343 & 440 & 120 & 415 & 527 & 231 & NA \\
\hline $4 b$ & 1280 & 2237 & 2337 & 428 & 1168 & 580 & NA \\
\hline $4 c$ & 60 & 220 & na & 227 & 2354 & 228 & NA \\
\hline $6 \mathbf{a}$ & 1084 & 890 & 3068 & 399 & 2280 & 3365 & NA \\
\hline $6 \mathbf{b}$ & 2420 & 2445 & 3017 & 2320 & 1820 & 3444 & 2234 \\
\hline $6 c$ & 210 & 120 & 283 & 359 & 206 & 2655 & NA \\
\hline 8 & 1101 & 1180 & 58 & 2766 & 180 & NA & NA \\
\hline 10a & 3124 & 2670 & 1165 & 4321 & 2166 & 112 & NA \\
\hline $10 \mathrm{~b}$ & 122 & 90 & 212 & 440 & 1877 & 436 & NA \\
\hline 10c & 40 & 60 & 152 & 320 & 2280 & 1663 & 690 \\
\hline 12 & 36 & 326 & 122 & 421 & 682 & 1293 & 1288 \\
\hline 13 & 3255 & 2674 & 1374 & 2693 & 2227 & 1438 & 25 \\
\hline 14 & 1235 & 3160 & 2168 & 410 & 2146 & 1263 & NA \\
\hline $17 \mathbf{a}$ & 2240 & 2388 & 1336 & 1120 & 1268 & 3844 & 320 \\
\hline $17 b$ & 140 & 66 & 42 & 59 & 822 & 625 & NA \\
\hline $17 \mathrm{c}$ & 2230 & 3199 & 3163 & 2791 & 2329 & 380 & NA \\
\hline 19 & 120 & 40 & 34 & 374 & 244 & 120 & NA \\
\hline 20 & 180 & 60 & 3265 & 365 & 4423 & 2533 & NA \\
\hline $22 a$ & 33 & 48 & 29 & 320 & 442 & 66 & NA \\
\hline $22 \mathrm{~b}$ & 350 & 38 & 1169 & 2349 & 2210 & 169 & 1180 \\
\hline $22 \mathrm{c}$ & 112 & 204 & 282 & 212 & 192 & 2230 & 2066 \\
\hline 22d & 38 & 65 & 88 & 235 & 370 & 1160 & NA \\
\hline $25 a$ & 3210 & 1264 & 1129 & 2231 & 388 & 64 & 1582 \\
\hline $25 \mathrm{~b}$ & 2188 & 3285 & 1723 & 2735 & 1078 & 219 & 428 \\
\hline $25 c$ & 66 & 1250 & 688 & 138 & 1109 & 260 & 360 \\
\hline CHS 828 & 25 & 2315 & 2067 & 1245 & 15 & 18 & NA \\
\hline
\end{tabular}

${ }^{a}$ NUGC: gastric cancer; DLDI: colon cancer; HA22T and HEPG2: liver cancer; HONE1: nasopharyngeal carcinoma; MCF: breast cancer; WI38: normal fibroblast cells. ${ }^{\mathrm{b}}$ The sample concentration that produces a $50 \%$ reduction in cell growth. 
vity which might be attributed to the existence of the annelated ring system. Compound $\mathbf{1 4}$ showed only moderate selective activity against HEPG2 ( $\left.\mathrm{IC}_{50} 410 \mathrm{nM}\right)$.

Considering the pyrazolo[3,4- $d]$ pyrimidines $17 \mathbf{a}-\mathbf{c}$, compound 17a bearing the unsubstituted phenyl moiety was found to lack cytotoxic activity. However, replacement of the phenyl group by the $4-\mathrm{OCH}_{3} \mathrm{C}_{6} \mathrm{H}_{4}$ moiety in $\mathbf{1 7 b}$ was accompanied by a dramatic enhancement of the activity appearing through its high activity against the six cancer cell lines with significant cytotoxicity against human liver cancer cell line HA22T ( $\mathrm{IC}_{50} 42 \mathrm{nM}$ ), HEPG2 $\left(\mathrm{IC}_{50} 59 \mathrm{nM}\right)$ and DLDI ( $\left.\mathrm{IC}_{50} 66 \mathrm{nM}\right)$. Meanwhile, 17c bearing a $4-\mathrm{BrC}_{6} \mathrm{H}_{4}$ moiety showed only selective activity against breast cancer cell line $\mathrm{MCF}\left(\mathrm{IC}_{50} 380 \mathrm{nM}\right)$. On the other hand, the 4-(ethoxymethylene)-3-methyl-1Hpyrazol-5(4H)-one derivative 19 exhibited more potent

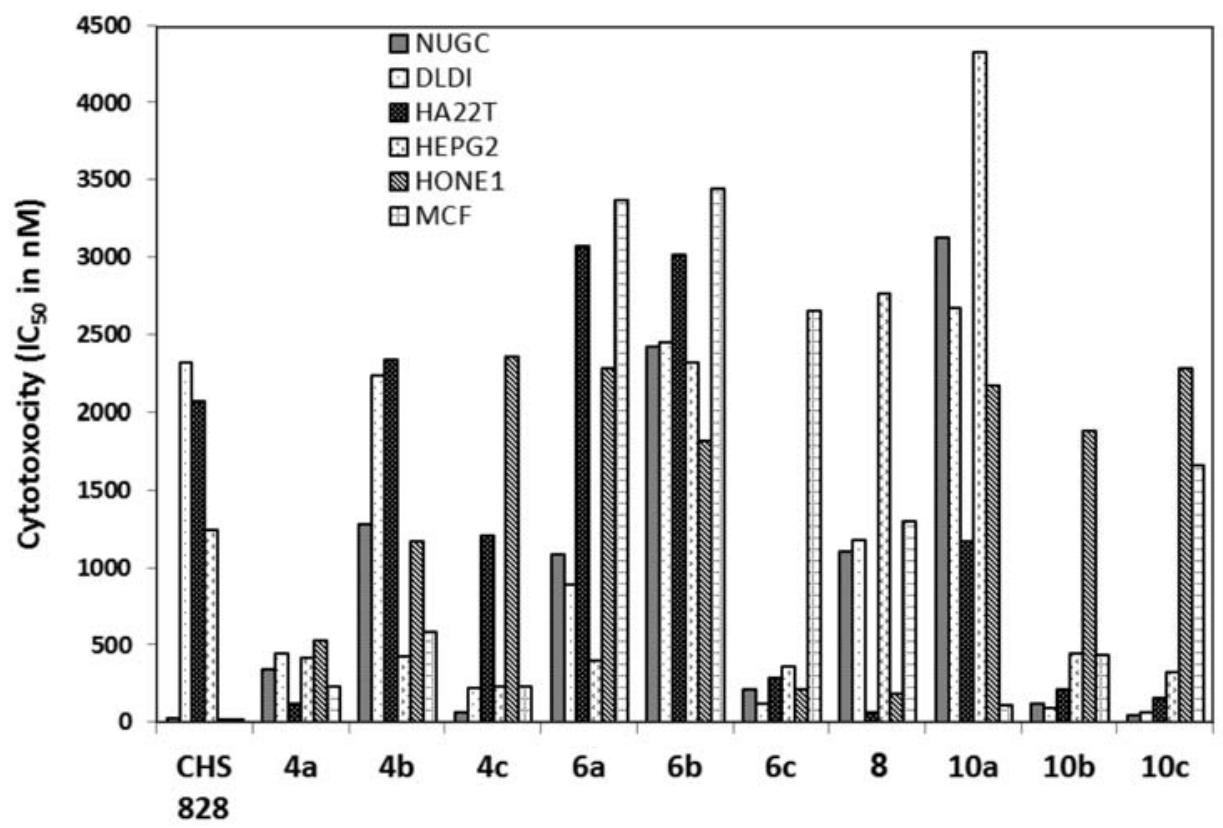

Figure 2. Cytotoxicity of compounds $4 \mathbf{4 a}-\mathbf{c}, \mathbf{6 a}-\mathbf{c}, \mathbf{8}, \mathbf{1 0 a}-\mathbf{c}$ and CHS 828 against NUGC (gastric cancer); DLDI (colon cancer); HA22T and HEPG2 (liver cancer); HONE1 (nasopharyngeal carcinoma); MCF (breast cancer).

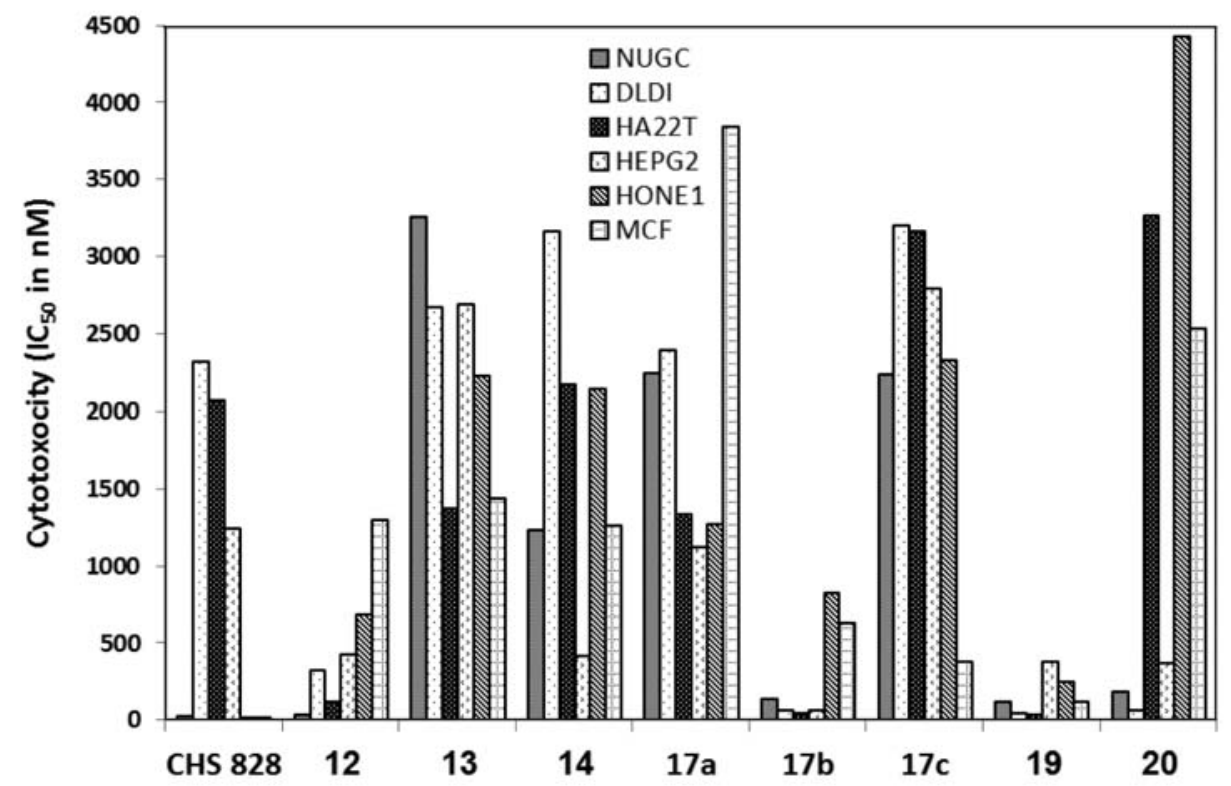

Figure 3. Cytotoxicity of compounds 12, 13, 14, 17a-c, 19, 20 and CHS 828 against NUGC (gastric cancer); DLDI (colon cancer); HA22T and HEPG2 (liver cancer); HONE1 (nasopharyngeal carcinoma); MCF (breast cancer). 


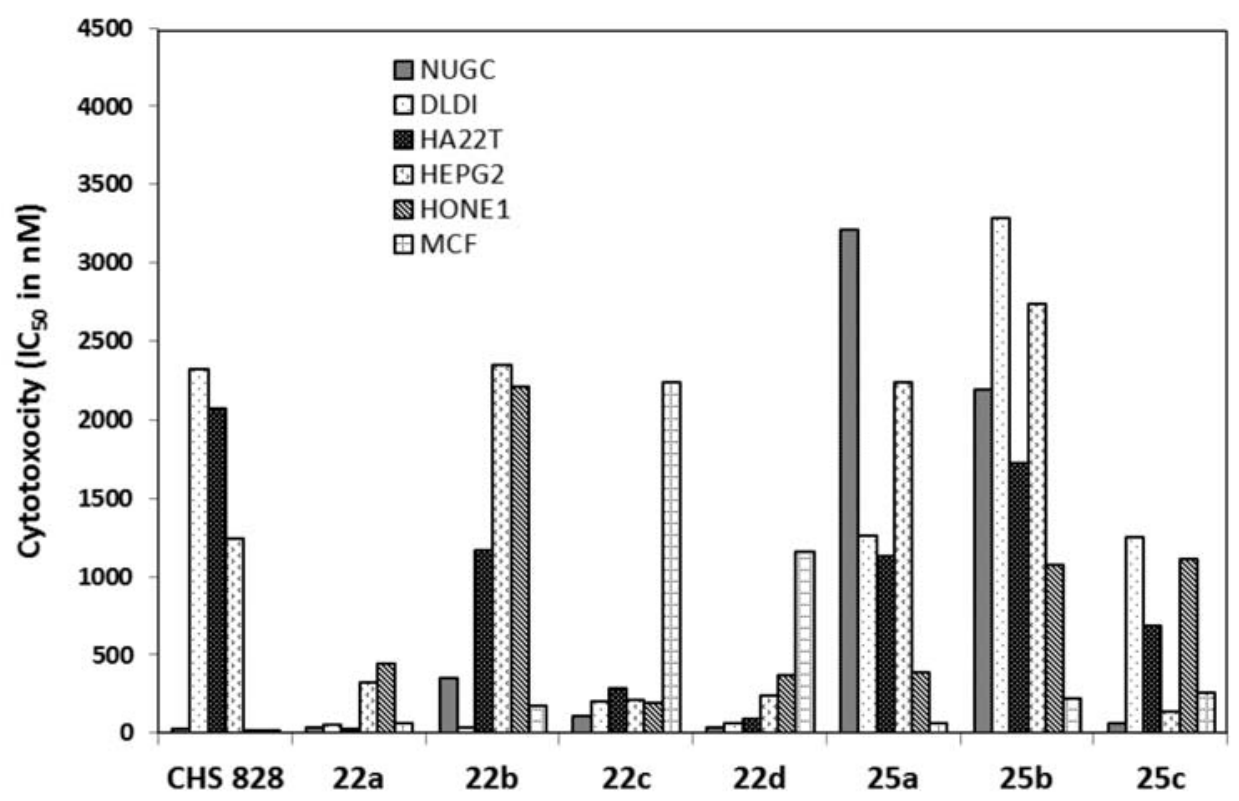

Figure 4. Cytotoxicity of compounds 22a-d, 25a-c and CHS 828 against NUGC (gastric cancer); DLDI (colon cancer); HA22T and HEPG2 (liver cancer); HONE1 (nasopharyngeal carcinoma); MCF (breast cancer).

cytotoxic activity than $\mathbf{2 0}$. Such activity was demonstrated in the high cytotoxicity against six human cancer cell lines with highest activity against $\mathrm{HA} 22 \mathrm{~T}\left(\mathrm{IC}_{50} 34 \mathrm{nM}\right)$ and DLDI $\left(\mathrm{IC}_{50} 40 \mathrm{nM}\right)$ which may be attributed to the presence of the ethoxymethylene moiety. Compound $\mathbf{2 0}$ showed selective cytotoxic effect against DLDI, NUGC and HEPG2 in the range of $\mathrm{IC}_{50} 60-365 \mathrm{nM}$. Furthermore, the pyrazolothiazole derivatives $22 \mathbf{a}, \mathbf{2 2 c}$ and $22 \mathrm{~d}$ exhibited potent to moderate broad spectrum activity. The results shown in Table 1 reveal that 3-methyl-6-phenyl$1 H$-pyrazolo[3,4- $d$ ] thiazole-5(6H)-thione (22a) showed the maximum cytotoxicity among the tested compounds towards the cancer cell lines. Compound $\mathbf{2 2 b}$ bearing a 4$\mathrm{OCH}_{3} \mathrm{C}_{6} \mathrm{H}_{4}$ showed potent cytotoxic activity against DLDI $\left(\mathrm{IC}_{50} 38 \mathrm{nM}\right)$. On the other hand, the $4-\mathrm{BrC}_{6} \mathrm{H}_{4}$ substituted derivative 22d showed almost three-fold larger activity than its $4-\mathrm{ClC}_{6} \mathrm{H}_{4}$ analogue 22c against NUGC, DLD1 and HA22T.

Considering the thiazole derivatives $\mathbf{2 5 a} \mathbf{a}-\mathbf{c}$, it is obvious that among the three compounds, the 4-(4-hydroxy3-phenylthiazol-2(3H)-ylidene)-3-methyl-1 $H$-pyrazol5(4H)-one (25c) demonstrated better cytotoxic activity compared to its analogues. Compounds $\mathbf{2 5 a}-\mathbf{c}$ showed potent to moderate activity against breast cancer MCF in the range of 64-260 nM. Most of the potent cytotoxic compounds affected the normal fibroblast cells W138 to a much lesser extent $\left(\mathrm{IC}_{50}>10,000 \mathrm{nM}\right)$.

In summary, it is of great value to conclude from Table 1 that compounds $4 \mathbf{a}, \mathbf{4 c}, \mathbf{6 c}, \mathbf{1 0 b}, \mathbf{1 0 c}, \mathbf{1 2}, \mathbf{1 7 b}, \mathbf{1 9}$, 20, 22a, 22b, 22c, 22d and 25c showed the highest cytotoxicity among the tested compounds. Moreover, the thiazole derivative 22a showed the maximum cytotoxicity among all compounds.

\section{3 Toxicity Testing}

Bioactive compounds are often toxic to shrimp larvae. Thus, in order to monitor these chemicals' in vivo lethality to shrimp larvae (Artemia salina), Brine-Shrimp Lethality Assay as described by Choudhary et al. in 2001 was used. ${ }^{30}$ Results were analysed with $\mathrm{LC}_{50}$ program to determine $\mathrm{LC}_{50}$ values and $95 \%$ confidence intervals. ${ }^{31}$ Results are given in Table 2 for the compounds which exhibited optimal cytotoxic effect against cancer cell lines; these are the following fourteen compounds $4 \mathbf{a}, \mathbf{4 c}, \mathbf{6 c}$, 10b, 10c, 12, 17b, 19, 20, 22a, 22b, 22c, 22d and 25c. The shrimp lethality assay is considered as a useful tool for preliminary assessment of toxicity, and it has been used for the detection of fungal toxins, plant extract toxicity, heavy metals, cyanobacteria toxins, pesticides, and cytotoxicity testing of dental materials, natural and synthetic organic compounds. It has also been shown that A. salina toxicity test results have a correlation with rodent and human acute oral toxicity data. Generally, a good correlation was obtained between A. salina toxicity test and the rodent data. Likewise, the predictive screening potential of the aquatic invertebrate tests for acute oral toxicity in humans, including $A$. salina toxicity test, was slightly better than the rat test for test compounds. ${ }^{32}$

In order to prevent the toxicity results from possible false effects originating from solubility of compounds and DMSO's possible toxicity effect, compounds were prepared by dissolving in DMSO in the suggested DMSO volume ranges. It is clear from Table 2 that compounds $4 \mathbf{a}, \mathbf{6 c}$, 17b, 22a and 22b were found to be nontoxic against the tested organisms. It is of great value to mention that compound 22a which is of optimum cytotoxicity was also found to be nontoxic. 
Table 2. Toxicity of the most optimal cytotoxic compounds against shrimp larvae

\begin{tabular}{|c|c|c|c|c|c|c|}
\hline Compound No. & Conc. $(\mu \mathrm{g} / \mathrm{ml})$ & Mortalitya & Toxicity & LC50 & Upper $95 \%$ lim. & Lower $95 \%$ lim \\
\hline \multirow[t]{3}{*}{$\overline{4 a}$} & 10 & 0 & Non toxic & 890.38 & - & - \\
\hline & 100 & 0 & & & & \\
\hline & 1000 & 4 & & & & \\
\hline \multirow[t]{3}{*}{$\overline{4 c}$} & 10 & 0 & Harmful & 14.18 & 560.12 & 160.30 \\
\hline & 100 & 4 & & & & \\
\hline & 1000 & 8 & & & & \\
\hline \multirow[t]{3}{*}{$\overline{6 c}$} & 10 & 0 & Non toxic & 451.19 & - & - \\
\hline & 100 & 0 & & & & \\
\hline & 1000 & 8 & & & & \\
\hline \multirow[t]{3}{*}{$\overline{10 b}$} & 10 & 5 & Very toxic & 112.65 & 469.28 & 230.41 \\
\hline & 100 & 8 & & & & \\
\hline & 1000 & 10 & & & & \\
\hline \multirow[t]{3}{*}{$\overline{10 c}$} & 10 & 2 & toxic & 100.00 & 104.2 & 157.62 \\
\hline & 100 & 4 & & & & \\
\hline & 1000 & 10 & & & & \\
\hline \multirow[t]{3}{*}{$\overline{12}$} & 10 & 0 & Harmful & 14.38 & 220.52 & 140.91 \\
\hline & 100 & 3 & & & & \\
\hline & 1000 & 8 & & & & \\
\hline \multirow[t]{3}{*}{$\overline{17 b}$} & 10 & 0 & Non-toxic & 945.21 & - & - \\
\hline & 100 & 0 & & & & \\
\hline & 1000 & 4 & & & & \\
\hline \multirow[t]{3}{*}{19} & 10 & 0 & toxic & 80.00 & 290.23 & 70.22 \\
\hline & 100 & 6 & & & & \\
\hline & 1000 & 10 & & & & \\
\hline \multirow[t]{3}{*}{20} & 10 & 2 & Very toxic & 251.19 & 650.30 & 159.17 \\
\hline & 100 & 8 & & & & \\
\hline & 1000 & 10 & & & & \\
\hline \multirow[t]{3}{*}{$\overline{22 a}$} & 10 & 0 & Non-toxic & 890.41 & - & - \\
\hline & 100 & 0 & & & & \\
\hline & 1000 & 8 & & & & \\
\hline \multirow[t]{3}{*}{$\overline{22 b}$} & 10 & 0 & Harmful & 18.72 & 630.21 & 440.01 \\
\hline & 100 & 2 & & & & \\
\hline & 1000 & 8 & & & & \\
\hline \multirow[t]{3}{*}{$\overline{22 d}$} & 10 & 0 & Non-toxic & 1000.0 & - & - \\
\hline & 100 & 0 & & & & \\
\hline & 1000 & 8 & & & & \\
\hline \multirow[t]{3}{*}{$\overline{25 c}$} & 10 & 0 & Harmful & 16.38 & 620.22 & 168.34 \\
\hline & 100 & 2 & & & & \\
\hline & 1000 & 10 & & & & \\
\hline
\end{tabular}

${ }^{\text {a }}$ Ten organisms (A. salina) tested for each concentration.

\section{Experimental}

\section{1. Chemistry}

All melting points were determined on a Stuart apparatus and the values given are uncorrected. IR spectra $\left(\mathrm{KBr}, \mathrm{cm}^{-1}\right)$ were determined on a Shimadzu IR 435 spectrophotometer (Faculty of Pharmacy, Cairo University, Egypt). ${ }^{1} \mathrm{H}$ and ${ }^{13} \mathrm{C}$ NMR spectra were recorded on Varian Gemini $300 \mathrm{MHz}$ (Microanalysis Center, Cairo University, Egypt) and Bruker Ascend $400 \mathrm{MHz}$ spectrophotometers (Microanalytical Unit, Faculty of
Pharmacy, Cairo University, Egypt) using TMS as internal standard. Chemical shift values are recorded in ppm on $\delta$ scale. Mass spectra were recorded on a Hewlett Packard 5988 spectrometer (Microanalysis Center, Cairo University, Egypt). Elemental analyses were carried out at the Microanalysis Center, Cairo University, Egypt; found values were within $\pm 0.35 \%$ of the theoretical ones. Progress of the reactions was monitored using thin layer chromatography (TLC) sheets pre-coated with UV fluorescent silica gel Merck 60F 254 and were visualized using UV lamp. 


\section{1. 1. General Procedure for the Synthesis of Compounds 4a-c and 6a-c}

To a solution of $1(0.98 \mathrm{~g}, 0.01 \mathrm{~mol})$ and the appropriate aldehyde $(0.01 \mathrm{~mol})$ in ethanol $(30 \mathrm{~mL})$ containing triethylamine $(1.0 \mathrm{~mL})$ either malononitrile $(0.66 \mathrm{~g}, 0.01$ mol) or ethyl cyanoacetate $(1.13 \mathrm{~g}, 0.01 \mathrm{~mol})$ was added. The reaction mixture, in each case, was heated under reflux for $1 \mathrm{~h}$, left to cool and the formed solid product, in each case, was collected by filtration and crystallized from ethanol.

3-Methyl-6-oxo-4-phenyl-1,6-dihydropyrano[2,3-c] pyrazole-5-carbonitrile (4a). Yield: $80 \%$; m.p.: $68-70$ ${ }^{\circ} \mathrm{C}$; IR $\left(\mathrm{KBr}, \mathrm{cm}^{-1}\right)$ v: $3439(\mathrm{NH}), 3032$ ( $\mathrm{CH}$ aromatic), 2981, 2953 (CH aliphatic), $2223(\mathrm{CN}), 1728(\mathrm{C}=\mathrm{O}) ;{ }^{1} \mathrm{H}$ NMR (DMSO- $\left.d_{6}\right) \delta: 2.49\left(\mathrm{~s}, 3 \mathrm{H}, \mathrm{CH}_{3}\right), 7.59-8.41(\mathrm{~m}, 5 \mathrm{H}$, Ar-H), 10.40 (s, 1H, NH, $\mathrm{D}_{2} \mathrm{O}$ exchangeable); ${ }^{13} \mathrm{C}$ NMR (DMSO- $d_{6}, 400 \mathrm{MHz}$ ): 14.4, 102.8, 116.0, 128.6, 129.5, $129.8,131.3,133.0,133.9,155.7,162.8,163.6$; MS (m/z,\%): $251\left(\mathrm{M}^{+}, 55\right)$. Anal. calcd. for $\mathrm{C}_{14} \mathrm{H}_{9} \mathrm{~N}_{3} \mathrm{O}_{2}: \mathrm{C}$, 66.93; H, 3.61; N, 16.73. Found: C, 66.75; H, 3.36; N, 16.95 .

4-(4-Methoxyphenyl)-3-methyl-6-oxo-1,6-dihydropyrano[2,3-c]pyrazole-5-carbonitrile (4b). Yield: $85 \%$; m.p.: $75-77^{\circ} \mathrm{C}$; IR $\left(\mathrm{KBr}, \mathrm{cm}^{-1}\right)$ v: $3385(\mathrm{NH}), 3050(\mathrm{CH}$ aromatic), 2954, 2935 (CH aliphatic), $2216(\mathrm{CN}), 1722$ $(\mathrm{C}=\mathrm{O}) ;{ }^{1} \mathrm{H}$ NMR $\left(\mathrm{DMSO}-d_{6}\right) \delta: 2.49\left(\mathrm{~s}, 3 \mathrm{H}, \mathrm{CH}_{3}\right), 3.87(\mathrm{~s}$, $\left.3 \mathrm{H}, \mathrm{OCH}_{3}\right), 6.88-8.32(\mathrm{~m}, 4 \mathrm{H}, \mathrm{Ar}-\mathrm{H}), 10.42(\mathrm{~s}, 1 \mathrm{H}, \mathrm{NH}$, $\mathrm{D}_{2} \mathrm{O}$ exchangeable); $\mathrm{MS}(\mathrm{m} / z, \%): 281\left(\mathrm{M}^{+}, 74\right)$. Anal. calcd. for $\mathrm{C}_{15} \mathrm{H}_{11} \mathrm{~N}_{3} \mathrm{O}_{3}$ : C, 64.05; H, 3.94; N, 14.94. Found: C, 63.90; H, 3.88; N, 14.82 .

4-(4-Chlorophenyl)-3-methyl-6-oxo-1,6-dihydropyrano[2,3-c]pyrazole-5-carbonitrile (4c). Yield: 78\%; m.p.: $110-112^{\circ} \mathrm{C}$; IR $\left(\mathrm{KBr}, \mathrm{cm}^{-1}\right)$ v: $3373(\mathrm{NH}), 3032(\mathrm{CH}$ aromatic), 2960 (CH aliphatic), $2223(\mathrm{CN}), 1728(\mathrm{C}=\mathrm{O}) ;{ }^{1} \mathrm{H}$ NMR (DMSO- $\left.d_{6}\right) \delta: 2.49\left(\mathrm{~s}, 3 \mathrm{H}, \mathrm{CH}_{3}\right), 7.66-8.42(\mathrm{~m}, 4 \mathrm{H}$, Ar-H), 10.38 (s, $1 \mathrm{H}, \mathrm{NH}, \mathrm{D}_{2} \mathrm{O}$ exchangeable); ${ }^{13} \mathrm{C}$ NMR (DMSO- $d_{6}, 400 \mathrm{MHz}$ ): 14.4, 103.4, 115.8, 128.9, 129.2,130.3, 131.6, 132.7, 138.5, 154.2, 162.1, 162.6; MS (m/z,\%): $285\left(\mathrm{M}^{+}, 66 \%\right)$. Anal. calcd. for $\mathrm{C}_{14} \mathrm{H}_{8} \mathrm{ClN}_{3} \mathrm{O}_{2}$ : C, 58.86; H, 2.82; N, 14.71. Found: C, 58.90; H, 2.88; N, 14.45 .

6-Amino-3-methyl-4-phenyl-1,4-dihydropyrano[2,3-c] pyrazole-5-carbonitrile (6a). ${ }^{27}$ Yield: 85\%; m.p.: 232-234 ${ }^{\circ} \mathrm{C}$; IR $\left(\mathrm{KBr}, \mathrm{cm}^{-1}\right)$ v: 3406, $3157\left(\mathrm{NH}_{2}, \mathrm{NH}\right)$, 3024 (CH aromatic), 2899, 2991 (CH aliphatic), 2017 $(\mathrm{CN}), 1635(\mathrm{C}=\mathrm{C}) ;{ }^{1} \mathrm{H}$ NMR (DMSO- $\left.d_{6}\right) \delta: 1.78$ (s, 3H, $\left.\mathrm{CH}_{3}\right), 4.58(\mathrm{~s}, 1 \mathrm{H}$, pyran $\mathrm{H}-4), 6.83\left(\mathrm{~s}, 2 \mathrm{H}, \mathrm{NH}_{2}, \mathrm{D}_{2} \mathrm{O}\right.$ exchangeable), 7.15-7.34 (m, 5H, Ar-H), $12.06(\mathrm{~s}, 1 \mathrm{H}, \mathrm{NH}$, $\mathrm{D}_{2} \mathrm{O}$ exchangeable); $\mathrm{MS}(\mathrm{m} / \mathrm{z}, \%): 252\left(\mathrm{M}^{+}, 12 \%\right)$. Anal. calcd. for $\mathrm{C}_{14} \mathrm{H}_{12} \mathrm{~N}_{4} \mathrm{O}: \mathrm{C}, 66.65 ; \mathrm{H}, 4.79 ; \mathrm{N}, 22.21$. Found: C, 66.38; H, 4.91; N, 21.95 .
6-Amino-4-(4-methoxyphenyl)-3-methyl-1,4-dihydro pyrano[2,3-c]pyazole-5-carbonitrile (6b). ${ }^{27}$ Yield: $89 \%$; m.p.: $210-212{ }^{\circ} \mathrm{C}$; IR $\left(\mathrm{KBr}, \mathrm{cm}^{-1}\right)$ v: $3483,3255\left(\mathrm{NH}_{2}\right.$, $\mathrm{NH}), 3107$ ( $\mathrm{CH}$ aromatic), 2960, 2912 (CH aliphatic), $2191(\mathrm{CN}) ;{ }^{1} \mathrm{H}$ NMR (DMSO- $\left.d_{6}\right) \delta: 1.78\left(\mathrm{~s}, 3 \mathrm{H}, \mathrm{CH}_{3}\right.$ ), $3.72\left(\mathrm{~s}, 3 \mathrm{H}, \mathrm{OCH}_{3}\right), 4.53(\mathrm{~s}, 1 \mathrm{H}$, pyran $\mathrm{H}-4), 6.85(\mathrm{~s}, 2 \mathrm{H}$, $\mathrm{NH}_{2}, \quad \mathrm{D}_{2} \mathrm{O}$ exchangeable $), \quad 6.87-7.09(\mathrm{~m}, \quad 4 \mathrm{H}$, Ar-H), 12.04 (s, 1H, NH, $\mathrm{D}_{2} \mathrm{O}$ exchangeable) $;{ }^{13} \mathrm{C}$ NMR (DMSO- $d_{\sigma}, 400 \mathrm{MHz}$ ): 10.2, 35.7, 55.4, 58.1, 98.3, 114.2, 121.3, 128.9, 129.2, 136.9, 155.2, 158.4, 161.2; MS (m/z,\%): $282\left(\mathrm{M}^{+}, 20\right)$. Anal. calcd. for $\mathrm{C}_{15} \mathrm{H}_{14} \mathrm{~N}_{4} \mathrm{O}_{2}: \mathrm{C}$, 63.82; H, 5.00; N, 19.85. Found: C, 63.50, H, 4.79, N 19.67.

6-Amino-4-(4-chlorophenyl)-3-methyl-1,4-dihydropyrano[2,3-c]pyrazole-5-carbonitrile $(\mathbf{6 c}){ }^{27}$ Yield: $82 \%$; m.p.: $234-236{ }^{\circ} \mathrm{C}$; IR $\left(\mathrm{KBr}, \mathrm{cm}^{-1}\right)$ v: $3479,3234\left(\mathrm{NH}_{2}\right.$, $\mathrm{NH}), 3050$ (CH aromatic), 2968, 2929 (CH aliphatic), $2193(\mathrm{CN}) ;{ }^{1} \mathrm{H}$ NMR (DMSO- $\left.d_{6}\right) \delta: 1.79\left(\mathrm{~s}, 3 \mathrm{H}, \mathrm{CH}_{3}\right)$, $4.63(\mathrm{~s}, 1 \mathrm{H}$, pyran $\mathrm{H}-4), 6.89$ (s, 2H, $\mathrm{NH}_{2}, \mathrm{D}_{2} \mathrm{O}$ exchangeable), 7.17-7.38 (m, 4H, Ar-H), $12.11\left(\mathrm{~s}, 1 \mathrm{H}, \mathrm{NH}, \mathrm{D}_{2} \mathrm{O}\right.$ exchangeable); ${ }^{13} \mathrm{C}$ NMR (DMSO- $d_{6}, 400 \mathrm{MHz}$ ): 10.2 , 36.1, 57.2, 97.7, 121.1, 128.9, 129.8, 131.7, 136.1, 143.9, 155.2, 161.4; MS (m/z,\%): $286\left(\mathrm{M}^{+}, 75\right)$. Anal. calcd. for $\mathrm{C}_{14} \mathrm{H}_{11} \mathrm{ClN}_{4} \mathrm{O}: \mathrm{C}, 58.65 ; \mathrm{H}, 3.87 ; \mathrm{N}, 19.54$. Found: $\mathrm{C}$, $58.45 ; \mathrm{H}, 3.91 ; \mathrm{N}, 19.33$.

\section{6-Amino-3-methyl-4-(pyridin-3-yl)-1,4-dihydropyrano} [2,3-c]pyrazole-5-carbonitrile $(8)^{27}$

To a solution of $\mathbf{1}(0.98 \mathrm{~g}, 0.01 \mathrm{~mol})$, pyridine-3-aldehyde $(1.7 \mathrm{~g}, 0.01 \mathrm{~mol})$ and malononitrile $(0.66 \mathrm{~g}, 0.01 \mathrm{~mol})$ were added. The reaction mixture was heated under reflux for $2 \mathrm{~h}$ then left to cool and the formed solid product was collected by filtration and crystallized from ethanol.

Yield: 92\%; m.p.: $216-217{ }^{\circ} \mathrm{C}$; IR $\left(\mathrm{KBr}, \mathrm{cm}^{-1}\right)$ v: 3394, $3354\left(\mathrm{NH}_{2}, \mathrm{NH}\right), 3066$ (CH aromatic), 2985, 2924 (CH aliphatic), $2193(\mathrm{CN}) ;{ }^{1} \mathrm{H}$ NMR (DMSO- $d_{6}$ ) $\delta: 1.79$ (s, 3H, $\left.\mathrm{CH}_{3}\right), 4.69$ (s, $1 \mathrm{H}$, pyran $\left.\mathrm{H}-4\right), 6.95\left(\mathrm{~s}, 2 \mathrm{H}, \mathrm{NH}_{2}\right.$, $\mathrm{D}_{2} \mathrm{O}$ exchangeable), 7.32-8.46 (m, $4 \mathrm{H}$, pyridine $\left.\mathrm{H}\right), 12.15$ (s, $1 \mathrm{H}, \mathrm{NH}, \mathrm{D}_{2} \mathrm{O}$ exchangeable); $\mathrm{MS}(\mathrm{m} / \mathrm{z}, \%): 253$ $\left(\mathrm{M}^{+}, 11\right)$. Anal. calcd. for $\mathrm{C}_{13} \mathrm{H}_{11} \mathrm{~N}_{5} \mathrm{O}: \mathrm{C}, 61.65 ; \mathrm{H}, 4.38$; $\mathrm{N}, 27.65$. Found: C, 61.90; H 4.52; N 27.33.

\section{1. 2. General Procedure for the Synthesis of Compounds 10a-c}

To a solution of $1(0.98 \mathrm{~g}, 0.01 \mathrm{~mol})$ in ethanol (30 $\mathrm{mL})$ containing triethylamine $(1.0 \mathrm{~mL})$ either benzaldehyde $(1.08 \mathrm{~g}, 0.01 \mathrm{~mol})$, 4-methoxybenzaldehyde (1.36 g, $0.01 \mathrm{~mol})$ or 4-chlorobenzaldehyde $(1.42 \mathrm{~g}, 0.01 \mathrm{~mol})$ and 2-aminoprop-1-ene-1,1,3-tricarbonitrile (1.32 g, 0.01 mol) was added. The whole reaction mixture, in each case was heated under reflux for $1 \mathrm{~h}$ then left to cool then poured onto ice/water mixture containing a few drops of hydrochloric acid. The formed solid product, in each case, was collected by filtration and crystallized from ethanol. 
5,7-Diamino-3-methyl-4-phenyl-1,4-dihydropyrazolo $\left[4^{\prime}, 3^{\prime}: 5,6\right]$ pyrano $[2,3-b]$ pyridine-6-carbonitrile (10a). Yield: $80 \%$; m.p.: $>300^{\circ} \mathrm{C}$; IR $\left(\mathrm{KBr}, \mathrm{cm}^{-1}\right)$ v: 3379 , 3213, $2922\left(2 \mathrm{NH}_{2}, \mathrm{NH}\right), 3070$ (CH aromatic), 2960, 2922 (CH aliphatic), $2199(\mathrm{CN}) ;{ }^{1} \mathrm{H}$ NMR (DMSO- $\left.d_{6}\right) \delta: 2.49$ (s, $\left.3 \mathrm{H}, \mathrm{CH}_{3}\right), 4.58(\mathrm{~s}, 1 \mathrm{H}$, pyran $\mathrm{H}-4), 7.10\left(\mathrm{~s}, 2 \mathrm{H}, \mathrm{NH}_{2}\right.$, $\mathrm{D}_{2} \mathrm{O}$ exchangeable), 7.06-7.95 (m, 5H, Ar-H), $8.02(\mathrm{~s}$, $2 \mathrm{H}, \mathrm{NH}_{2}, \mathrm{D}_{2} \mathrm{O}$ exchangeable), $11.01\left(\mathrm{~s}, 1 \mathrm{H}, \mathrm{NH}, \mathrm{D}_{2} \mathrm{O}\right.$ exchangeable); ${ }^{13} \mathrm{C}$ NMR (DMSO- $d_{6}, 400 \mathrm{MHz}$ ): 14.4, 36.9, $68.3,91.4,114.1,127.1,128.3,129.1,137.3,144.9$, 146.8, 148.4, 150.6, 154.3, 154.9; MS ( $\mathrm{m} / \mathrm{z}, \%): 318\left(\mathrm{M}^{+}\right.$, 63). Anal. calcd. for $\mathrm{C}_{17} \mathrm{H}_{14} \mathrm{~N}_{6} \mathrm{O}: \mathrm{C}, 64.14 ; \mathrm{H}, 4.43 ; \mathrm{N}$, 26.40. Found: C, 63.90; H, 4.68; N, 26.15.

5,7-Diamino-4-(4-methoxyphenyl)-3-methyl-1,4-dihydropyrazolo- $\left[4^{\prime}, 3^{\prime}: 5,6\right]$ pyrano $[2,3-b]$ pyridine-6-carbonitrile (10b). Yield: 85\%; m.p.: $203-205{ }^{\circ} \mathrm{C}$; IR (KBr, $\left.\mathrm{cm}^{-1}\right)$ v: $3354,3263,3130\left(2 \mathrm{NH}_{2}, \mathrm{NH}\right), 3050(\mathrm{CH}$ aromatic), 2957, 2912 (CH aliphatic), $2206(\mathrm{CN}) ;{ }^{1} \mathrm{H}$ NMR $\left(\mathrm{DMSO}-d_{6}\right) \delta: 2.49\left(\mathrm{~s}, 3 \mathrm{H}, \mathrm{CH}_{3}\right), 3.83\left(\mathrm{~s}, 3 \mathrm{H}, \mathrm{OCH}_{3}\right), 4.86$ (s, 1H, pyran $\mathrm{H}-4), 6.80$ (s, $2 \mathrm{H}, \mathrm{NH}_{2}, \mathrm{D}_{2} \mathrm{O}$ exchangeable), 7.06-7.95 (m, 4H, Ar-H), 7.95 (s, 2H, NH ${ }_{2}, \mathrm{D}_{2} \mathrm{O}$ exchangeable), 11.01 (s, 1H, NH, $\mathrm{D}_{2} \mathrm{O}$ exchangeable); ${ }^{13} \mathrm{C}$ NMR (DMSO- $d_{6}, 400 \mathrm{MHz}$ ): $10.5,39.3,55.5,105.4,114.1$, $114.8,128.6,130.4,133.1,143.8,146.9,148.3,152.0$, 160.7, 161.1, 162.1; MS (m/z,\%): $348\left(\mathrm{M}^{+}, 83.91\right)$. Anal. calcd. for $\mathrm{C}_{18} \mathrm{H}_{16} \mathrm{~N}_{6} \mathrm{O}_{2}: \mathrm{C}, 62.06 ; \mathrm{H}, 4.63 ; \mathrm{N}, 24.12$. Found: C, 62.39; H, 4.71; N, 23.98 .

5,7-Diamino-4-(4-chlorophenyl)-3-methyl-1,4-dihydropyrazolo- $\left[4^{\prime}, 3^{\prime}: 5,6\right]$ pyrano $[2,3-b]$ pyridine-6-carbonitrile (10c). Yield: $82 \%$; m.p.: $>300^{\circ} \mathrm{C}$; $\mathrm{IR}\left(\mathrm{KBr}, \mathrm{cm}^{-1}\right) \mathrm{v}$ : 3406, $3290\left(\mathrm{NH}_{2}, \mathrm{NH}\right), 3050$ (CH aromatic), 2927, 2912 (CH aliphatic), 1681, $1662(\mathrm{C}=\mathrm{O}) ;{ }^{1} \mathrm{H}$ NMR (DMSO- $\left.d_{6}\right)$ $\delta: 2.50\left(\mathrm{~s}, 3 \mathrm{H}, \mathrm{CH}_{3}\right), 4.57(\mathrm{~s}, 1 \mathrm{H}$, pyran $\mathrm{H}-4), 7.15(\mathrm{~s}, 2 \mathrm{H}$, $\mathrm{NH}_{2}, \mathrm{D}_{2} \mathrm{O}$ exchangeable), 7.17-7.92 (m, $\left.4 \mathrm{H}, \mathrm{Ar}-\mathrm{H}\right), 8.72$ (s, $2 \mathrm{H}, \mathrm{NH}_{2}, \mathrm{D}_{2} \mathrm{O}$ exchangeable), $11.03\left(\mathrm{~s}, 1 \mathrm{H}, \mathrm{NH}, \mathrm{D}_{2} \mathrm{O}\right.$ exchangeable); ${ }^{13} \mathrm{C}$ NMR (DMSO- $d_{6}, 400 \mathrm{MHz}$ ): 10.5 , 39.3, 67.2 105.4, 116.7, 128.4, 130.5, 130.7, 134.0, 143.9, 146.8, 150.6, 158.2, 160.7, 161.3; MS $(\mathrm{m} / \mathrm{z}, \%): 353\left(\mathrm{M}^{+}\right.$, 59). Anal. calcd. for $\mathrm{C}_{17} \mathrm{H}_{13} \mathrm{ClN}_{6} \mathrm{O}: \mathrm{C}, 57.88 ; \mathrm{H}, 3.71 ; \mathrm{N}$, 23.82. Found: C, 57.58; H, 3.88; N 23.56.

\section{1. 3. 1-(5-Cyano-4-(4-methoxyphenyl)-3- methyl-1,4-dihydropyrano[2,3-c]pyrazol- 6-yl)-3-phenylthiourea (12)}

To a solution of compound $6 \mathrm{~b}(2.66 \mathrm{~g}, 0.01 \mathrm{~mol})$ in dioxane $(40 \mathrm{~mL})$ containing triethylamine $(1.0 \mathrm{~mL})$, phenylisothiocyanate $(1.30 \mathrm{~g}, 0.01 \mathrm{~mol})$ was added. The reaction mixture was heated under reflux for $2 \mathrm{~h}$. The formed solid product was collected by filtration and crystallized from ethanol. Yield: $90 \%$; m.p.: $192-194{ }^{\circ} \mathrm{C}$; IR (KB$\left.\mathrm{r}, \mathrm{cm}^{-1}\right) \mathrm{v}: 3360,3315(2 \mathrm{NH}), 3068$ (CH aromatic), 2962, 2926 (CH aliphatic), $2191(\mathrm{CN}), 1170(\mathrm{C}=\mathrm{S}) ;{ }^{1} \mathrm{H}$ NMR $\left(\mathrm{DMSO}-d_{6}\right) \delta: 1.76\left(\mathrm{~s}, 3 \mathrm{H}, \mathrm{CH}_{3}\right), 3.72(\mathrm{~s}, 3 \mathrm{H}, \mathrm{OCH} 3)$, $4.53(\mathrm{~s}, 1 \mathrm{H}$, pyran $\mathrm{H}-4), 6.78,6.80\left(2 \mathrm{~s}, 2 \mathrm{H}, 2 \mathrm{NH}, \mathrm{D}_{2} \mathrm{O}\right.$ exchangeable), 6.88-7.08 (m, 9H, Ar-H), 12.04 (s, 1H, $\mathrm{NH}, \mathrm{D}_{2} \mathrm{O}$ exchangeable); $\mathrm{MS}(\mathrm{m} / z, \%): 417\left(\mathrm{M}^{+}, 25\right)$. Anal. calcd. for $\mathrm{C}_{22} \mathrm{H}_{19} \mathrm{~N}_{5} \mathrm{O}_{2} \mathrm{~S}: \mathrm{C}, 63.29 ; \mathrm{H}, 4.59 ; \mathrm{N}$, 16.78. Found: C, 63.09; H, 4.68; N, 16.90 .

\section{1. 4. General Procedure for Synthesis of Compounds 13 and 14}

To a solution of compound $1(0.98 \mathrm{~g}, 0.01 \mathrm{~mol})$ and salicylaldehyde $(1.23 \mathrm{~g}, 0.01 \mathrm{~mol})$ in ethanol $(30 \mathrm{~mL})$ containing triethylamine $(1.0 \mathrm{~mL})$, either malononitrile $(0.66$ $\mathrm{g}, 0.01 \mathrm{~mol})$ or ethyl cyanoacetate $(1.13 \mathrm{~g}, 0.01 \mathrm{~mol})$ were added. The whole reaction mixture, in each case, was heated under reflux for $2 \mathrm{~h}$, left to cool then poured onto ice/water mixture containing few drops of hydrochloric acid. The formed solid product, in each case, was collected by filtration and crystallized from ethanol.

5-Amino-1-methyl-3H-chromeno[4',3':4,5]pyrano [2,3-c]pyrazol-6(11bH)-one (13). Yield: 78\%; m.p.: $>300{ }^{\circ} \mathrm{C}$; IR $\left(\mathrm{KBr}, \mathrm{cm}^{-1}\right)$ v: $3340,3242\left(\mathrm{NH}_{2}, \mathrm{NH}\right), 3050$ (CH aromatic), 2999, 2958 (CH aliphatic); ${ }^{1} \mathrm{H}$ NMR $\left(\mathrm{DMSO}-d_{6}\right) \delta$ : $2.48\left(\mathrm{~s}, 3 \mathrm{H}, \mathrm{CH}_{3}\right), 4.10(\mathrm{~s}, 1 \mathrm{H}$, pyran $\mathrm{H})$, 4.14 (s, $2 \mathrm{H}, \mathrm{NH}_{2}, \mathrm{D}_{2} \mathrm{O}$ exchangeable), 7.29-7.57 (m, 4H, Ar-H), 11.01 (s, 1H, NH, $\mathrm{D}_{2} \mathrm{O}$ exchangeable); ${ }^{13} \mathrm{C}$ NMR (DMSO- $\left.d_{6}, 400 \mathrm{MHz}\right): 10.6,26.3,115.6,119.1,125.3$, 125.7, 126.0, 134.9, 142.3,152.4, 159.3, 162.0, 162.5, 163.0; MS (m/z,\%): $269\left(\mathrm{M}^{+}, 21\right)$. Anal. calcd. for $\mathrm{C}_{14} \mathrm{H}_{11} \mathrm{~N}_{3} \mathrm{O}_{3}: \mathrm{C}, 62.45 ; \mathrm{H}, 4.12 ; \mathrm{N}, 15.61$. Found: $\mathrm{C}$, $62.39 ; \mathrm{H}, 4.18 ; \mathrm{N}, 15.88$.

1-Methyl-3H-chromeno[4',3':4,5]pyrano[2,3-c]pyrazole-5,6-dione (14). Yield: $82 \%$; m.p.: $>300{ }^{\circ} \mathrm{C}$; IR (KBr, $\left.\mathrm{cm}^{-1}\right) \mathrm{v}: 3350(\mathrm{NH}), 3050$ (CH aromatic), 2927, $2912(\mathrm{CH}$ aliphatic), $1722(\mathrm{C}=\mathrm{O}) ;{ }^{1} \mathrm{H}$ NMR (DMSO- $\left.d_{6}\right) \delta: 2.48$ (s, $\left.3 \mathrm{H}, \mathrm{CH}_{3}\right), 6.93-7.60(\mathrm{~m}, 4 \mathrm{H}, \mathrm{Ar}-\mathrm{H}), 11.01$ (s, 1H, NH, $\mathrm{D}_{2} \mathrm{O}$ exchangeable); $\mathrm{MS}(\mathrm{m} / \mathrm{z}, \%): 268\left(\mathrm{M}^{+}, 29\right)$. Anal. calcd. for $\mathrm{C}_{14} \mathrm{H}_{8} \mathrm{~N}_{2} \mathrm{O}_{4}$ : C, 62.69; H, 3.01; N, 10.44. Found: C, $62.90 ; \mathrm{H}, 3.20 ; \mathrm{N}, 10.64$.

\section{1. 5. General Procedure for Synthesis of Compounds 17a-c}

To a solution of compound $1(0.98 \mathrm{~g}, 0.01 \mathrm{~mol})$ in ethanol $(30 \mathrm{~mL})$ containing triethylamine $(1.0 \mathrm{~mL})$, the appropriate aldehyde $(0.01 \mathrm{~mol})$ and thiourea $(0.76 \mathrm{~g}$, $0.01 \mathrm{~mol}$ ) were added. The whole reaction mixture, in each case was heated under reflux for $1 \mathrm{~h}$, left to cool then poured onto ice/water mixture containing few drops of hydrochloric acid. The formed solid product, in each case, was collected by filtration and crystallized from ethanol.

3-Methyl-4-phenyl-1H-pyrazolo[3,4- $d]$ pyrimidine-6 (7H)-thione (17a). Yield: $92 \%$; m.p.: $148-150{ }^{\circ} \mathrm{C}$; IR $\left(\mathrm{KBr}, \mathrm{cm}^{-1}\right)$ v: 3348, $3310(2 \mathrm{NH}), 3050(\mathrm{CH}$ aromatic), 
2949, $2912\left(\mathrm{CH}\right.$ aliphatic), $1242(\mathrm{C}=\mathrm{S}) ;{ }^{1} \mathrm{H}$ NMR $\left(\right.$ DMSO- $\left.d_{6}\right) \delta: 1.76\left(\mathrm{~s}, 3 \mathrm{H}, \mathrm{CH}_{3}\right), 3.86\left(\mathrm{~s}, 1 \mathrm{H}, \mathrm{NH}, \mathrm{D}_{2} \mathrm{O}\right.$ exchangeable), 7.12-7.95 (m, 5H, Ar-H), $11.20(\mathrm{~s}, 1 \mathrm{H}$, $\mathrm{NH}, \mathrm{D}_{2} \mathrm{O}$ exchangeable); ${ }^{13} \mathrm{C}$ NMR (DMSO- $d_{6}, 400$ $\mathrm{MHz}): 14.1,114.6,128.1,128.9,129.8,133.9,143.5$, 155.7, 160.8, 184.3; MS (m/z,\%): $242\left(\mathrm{M}^{+}, 12\right)$. Anal. calcd. for $\mathrm{C}_{12} \mathrm{H}_{10} \mathrm{~N}_{4} \mathrm{~S}: \mathrm{C}, 59.48 ; \mathrm{H}, 4.16 ; \mathrm{N}, 23.12$. Found: $\mathrm{C}$, 59.27; H, 4.19; N, 23.33.

4-(4-Methoxyphenyl)-3-methyl-1H-pyrazolo[3,4-d] pyrimidine-6(7H)-thione (17b). Yield: 85\%; m.p.: $154-155{ }^{\circ} \mathrm{C}$; IR $\left(\mathrm{KBr}, \mathrm{cm}^{-1}\right)$ v: $3367,3340(2 \mathrm{NH}), 3085$ (CH aromatic), 2977, 2914 (CH aliphatic), $1257(\mathrm{C}=\mathrm{S})$; ${ }^{1} \mathrm{H}$ NMR (DMSO- $\left.d_{6}\right) \delta: 1.76\left(\mathrm{~s}, 3 \mathrm{H}, \mathrm{CH}_{3}\right), 3.73(\mathrm{~s}, 1 \mathrm{H}$, $\mathrm{NH}, \mathrm{D}_{2} \mathrm{O}$ exchangeable), 3.87 (s, $3 \mathrm{H}, \mathrm{OCH} 3$ ), 7.08-8.60 (m, 4H, Ar- $\mathrm{H}), 11.14$ (s, 1H, NH, $\mathrm{D}_{2} \mathrm{O}$ exchangeable) $;{ }^{13} \mathrm{C}$ NMR (DMSO- $d_{6}, 400 \mathrm{MHz}$ ): $13.5,55.8,114.9,127.1$, $130.4,132.3,136.7,146.2,152.3,162.1,184.2$; MS (m/z,\%): $272\left(\mathrm{M}^{+}, 25\right)$. Anal. calcd. for $\mathrm{C}_{13} \mathrm{H}_{12} \mathrm{~N}_{4} \mathrm{OS}$ : C, 57.34; H, 4.44; N, 20.57. Found: C, 57.56; H, 4.58; N, 20.68 .

4-(4-Bromophenyl)-3-methyl-1H-pyrazolo[3,4- $d]$ pyri midine-6(7H)-thione (17c). Yield: 89\%; mp: 154-155 ${ }^{\circ} \mathrm{C}$; IR $\left(\mathrm{KBr}, \mathrm{cm}^{-1}\right)$ v: $3373,3334(2 \mathrm{NH}), 3085(\mathrm{CH}$ aromatic), 2977, 2914 (CH aliphatic), 1245 (C=S); ${ }^{1} \mathrm{H}$ NMR $\left(\mathrm{DMSO}-d_{6}\right)$ 8: $2.49\left(\mathrm{~s}, 3 \mathrm{H}, \mathrm{CH}_{3}\right), 3.77\left(\mathrm{~s}, 1 \mathrm{H}, \mathrm{NH}, \mathrm{D}_{2} \mathrm{O}\right.$ exchangeable), 7.05-8.52 (m, 4H, Ar-H), $11.25(\mathrm{~s}, 1 \mathrm{H}$, $\mathrm{NH}, \mathrm{D}_{2} \mathrm{O}$ exchangeable); $\mathrm{MS}(\mathrm{m} / z, \%): 321\left(\mathrm{M}^{+}, 18\right)$. Anal. calcd. for $\mathrm{C}_{12} \mathrm{H}_{9} \mathrm{BrN}_{4} \mathrm{~S}: \mathrm{C}, 44.87 ; \mathrm{H}, 2.82 ; \mathrm{N}$, 17.44. Found: C, 44.56; H, 2.62; N, 17.68 .

\section{1. 6. 4-(Ethoxymethylene)-3-methyl-1H -pyrazol-5(4H)-one (19)}

A mixture of $1(0.98 \mathrm{~g}, 0.01 \mathrm{~mol})$ and triethylorthoformate $(1.48 \mathrm{~mL}, 0.01 \mathrm{~mol})$ were heated in an oil bath at $120{ }^{\circ} \mathrm{C}$ for $30 \mathrm{~min}$ then left to cool. The remaining residue was triturated with ethanol and the formed solid product was collected by filtration and crystallized from acetic acid.Yield: $80 \%$; m.p.: $>300{ }^{\circ} \mathrm{C}$; IR $\left(\mathrm{KBr}, \mathrm{cm}^{-1}\right)$ v: 3125 (NH), 2956, 2920 (CH aliphatic), $1678(\mathrm{C}=\mathrm{O}) ;{ }^{1} \mathrm{H}$ NMR $\left(\right.$ DMSO- $\left.d_{6}\right) \delta: 1.29\left(\mathrm{t}, 3 \mathrm{H}, J=7.02 \mathrm{~Hz}, \mathrm{CH}_{3}\right), 2.22(\mathrm{~s}, 3 \mathrm{H}$, $\left.\mathrm{CH}_{3}\right), 4.15$ (q, $\left.2 \mathrm{H}, J=7.02 \mathrm{~Hz}, \mathrm{CH}_{2}\right), 7.38(\mathrm{~s}, 1 \mathrm{H}, \mathrm{CH}=\mathrm{C})$, $12.04\left(\mathrm{~s}, 1 \mathrm{H}, \mathrm{NH}, \mathrm{D}_{2} \mathrm{O}\right.$ exchangeable); ${ }^{13} \mathrm{C}$ NMR (DMSO- $d_{6}, 400 \mathrm{MHz}$ ): 12.9, 14.7, 67.0, 107.3, 152.7, 169.5, 177.5; MS (m/z,\%): $154\left(\mathrm{M}^{+}, 20\right)$. Anal. calcd. for $\mathrm{C}_{7} \mathrm{H}_{10} \mathrm{~N}_{2} \mathrm{O}_{2}$ : C, 54.54; $\mathrm{H}, 6.54 ; \mathrm{N}, 18.17$. Found: C, 54.39; $\mathrm{H}, 6.88 ; \mathrm{N}, 17.98$.

\section{1. 7. 2-((3-Methyl-5-oxo-1H-pyrazol-4(5H)-yli- dene)methyl)malononitrile (20)}

A mixture of $1(0.98 \mathrm{~g}, 0.01 \mathrm{~mol})$, malonitrile (0.66 $\mathrm{g}, 0.01 \mathrm{~mol})$, ethyl orthoformate $(1.48 \mathrm{~mL}, 0.01 \mathrm{~mol})$ and triethylamine $(1 \mathrm{~mL})$ in ethanol $(30 \mathrm{~mL})$ was heated under reflux for $2 \mathrm{hr}$. The reaction mixture was left to cool and the solid product was filtered, dried and cystallized from ethanol.Yield: $80 \%$; m.p.: $>300{ }^{\circ} \mathrm{C}$; IR $\left(\mathrm{KBr}, \mathrm{cm}^{-1}\right)$ v: $3346(\mathrm{NH}), 2985$ (CH aliphatic), 2204, 2179 (2 CN), 1677 $(\mathrm{C}=\mathrm{O}) ;{ }^{1} \mathrm{H}$ NMR $\left(\mathrm{DMSO}-d_{6}\right) \delta: 2.49$ (s, 3H, $\left.\mathrm{CH}_{3}\right), 4.01$ (s, $1 \mathrm{H}, \mathrm{CH}), 8.66(\mathrm{~s}, 1 \mathrm{H}, \mathrm{CH}=\mathrm{C}), 12.04\left(\mathrm{~s}, 1 \mathrm{H}, \mathrm{NH}, \mathrm{D}_{2} \mathrm{O}\right.$ exchangeable); MS $(\mathrm{m} / z, \%): 174\left(\mathrm{M}^{+}, 32\right)$. Anal. calcd. for $\mathrm{C}_{8} \mathrm{H}_{6} \mathrm{~N}_{4} \mathrm{O}: \mathrm{C}, 55.17 ; \mathrm{H}, 3.47 ; \mathrm{N}, 32.17$. Found: $\mathrm{C}$, 55.39; $\mathrm{H}, 3.48 ; \mathrm{N}, 32.32$.

\section{1. 8. General Procedure for Synthesis of Compounds 22a-d}

To a solution of compound 1 (0.98 g, $0.01 \mathrm{~mol})$ in 1,4-dioxane $(30 \mathrm{~mL})$ containing triethylamine $(1.0 \mathrm{~mL})$ each of elemental sulfur $(0.32 \mathrm{~g}, 0.01 \mathrm{~mol})$ and the appropriate arylisothiocyanate $(0.01 \mathrm{~mol})$ was added. The whole reaction mixture, in each case was heated under reflux for $3 \mathrm{~h}$, left to cool then poured onto ice/water mixture containing few drops of hydrochloric acid. The formed solid product was collected by filtration and crystallized from ethanol.

3-Methyl-6-phenyl-1 $H$-pyrazolo[3,4-d]thiazole-5(6H)thione (22a). Yield: $90 \%$; m.p.: $192-194{ }^{\circ} \mathrm{C}$; IR (KBr, $\mathrm{cm}^{-1}$ ) v: $3205(\mathrm{NH}), 3034$ (CH aromatic), 2976 (CH aliphatic), 1256 (C=S); ${ }^{1} \mathrm{H}$ NMR (DMSO- $d_{6}$ ) $\delta: 2.49$ (s, 3H, $\left.\mathrm{CH}_{3}\right), 7.09-7.50(\mathrm{~m}, 5 \mathrm{H}, \mathrm{Ar}-\mathrm{H}), 9.75\left(\mathrm{~s}, 1 \mathrm{H}, \mathrm{NH}, \mathrm{D}_{2} \mathrm{O}\right.$ exchangeable); ${ }^{13} \mathrm{C}$ NMR (DMSO- $d_{6}, 400 \mathrm{MHz}$ ): 12.27 , 124.5, 128.5,128.9, 129.4, 130.4, 137.8, 139.2, 180.1; MS (m/z,\%): $247\left(\mathrm{M}^{+}, 18\right)$. Anal. calcd. for $\mathrm{C}_{11} \mathrm{H}_{9} \mathrm{~N}_{3} \mathrm{~S}_{2}: \mathrm{C}$, 53.42; H, 3.67; N, 16.99. Found: C, 53.59; H, 3.88; N, 16.79 .

6-(4-Methoxyphenyl)-3-methyl-1H-pyrazolo[3,4- $d]$ thiazole-5(6H)-thione (22b). Yield: 89\%; m.p.: 160-162 ${ }^{\circ} \mathrm{C}$; IR $\left(\mathrm{KBr}, \mathrm{cm}^{-1}\right)$ v: $3217(\mathrm{NH}), 3020$ (CH aromatic), $2976 \quad\left(\mathrm{CH}\right.$ aliphatic), $1246 \quad(\mathrm{C}=\mathrm{S}) ; \quad{ }^{1} \mathrm{H} \quad \mathrm{NMR}$ $\left(\mathrm{DMSO}-d_{6}\right) \delta: 2.49$ (s, 3H, CH $), 3.78\left(\mathrm{~s}, 3 \mathrm{H}, \mathrm{OCH}_{3}\right)$, 6.87-7.33 (m, 4H, Ar-H), $9.40\left(\mathrm{~s}, 1 \mathrm{H}, \mathrm{NH}, \mathrm{D}_{2} \mathrm{O}\right.$ exchangeable); ${ }^{13} \mathrm{C}$ NMR (DMSO- $\left.d_{6}, 400 \mathrm{MHz}\right): 10.1,55.7,94.0,120.3$, 127.8, 129.4, 132.7, 137.2, 156.9, 180.7; MS (m/z,\%): 277 $\left(\mathrm{M}^{+}, 25\right)$. Anal. calcd. for $\mathrm{C}_{12} \mathrm{H}_{11} \mathrm{~N}_{3} \mathrm{OS}_{2}: \mathrm{C}, 51.96 ; \mathrm{H}, 4.00$; $\mathrm{N}, 15.15$. Found: C, 51.79; H, 3.88; N, 15.30.

6-(4-Chlorophenyl)-3-methyl- $1 H$-pyrazolo $[3,4-d]$ thiazole-5(6H)-thione (22c). Yield: $89 \%$; m.p.: $155-157{ }^{\circ} \mathrm{C}$, IR $\left(\mathrm{KBr}, \mathrm{cm}^{-1}\right)$ v: $3211(\mathrm{NH}), 3014(\mathrm{CH}$ aromatic), 2924 (CH aliphatic), $1282\left(\mathrm{C}=\mathrm{S}\right.$ ); ${ }^{1} \mathrm{H}$ NMR (DMSO- $d_{6}$ ) $\delta: 2.49$ (s, 3H, $\mathrm{CH}_{3}$ ), 7.36-7.85 (m, 4H, Ar-H), 9.95 (s, 1H, NH, $\mathrm{D}_{2} \mathrm{O}$ exchangeable); $\mathrm{MS}(\mathrm{m} / \mathrm{z}, \%): 281\left(\mathrm{M}^{+}, 40\right)$. Anal. calcd. for $\mathrm{C}_{11} \mathrm{H}_{8} \mathrm{ClN}_{3} \mathrm{~S}_{2}$ : C, 46.89; H, 2.86; N, 14.91. Found: $\mathrm{C}, 47.09 ; \mathrm{H}, 2.88 ; \mathrm{N}, 14.79$.

6-(4-Bromophenyl)-3-methyl-1H-pyrazolo[3,4-d]thiazole-5(6H)-thione (22d). Yield: $85 \%$;m.p.: $142-144{ }^{\circ} \mathrm{C}$, 
IR $\left(\mathrm{KBr}, \mathrm{cm}^{-1}\right)$ v: $3205(\mathrm{NH}), 3012$ (CH aromatic), 2976 (CH aliphatic), $1282(\mathrm{C}=\mathrm{S}) ;{ }^{1} \mathrm{H}$ NMR (DMSO- $\left.d_{6}\right) \delta: 2.49$ (s, 3H, $\left.\mathrm{CH}_{3}\right), 7.25-7.81(\mathrm{~m}, 4 \mathrm{H}, \mathrm{Ar}-\mathrm{H}), 9.96(\mathrm{~s}, 1 \mathrm{H}, \mathrm{NH}$, $\mathrm{D}_{2} \mathrm{O}$ exchangeable); $\mathrm{MS}(\mathrm{m} / \mathrm{z}, \%): 326\left(\mathrm{M}^{+}, 28\right)$. Anal. calcd. for $\mathrm{C}_{11} \mathrm{H}_{8} \mathrm{BrN}_{3} \mathrm{~S}_{2}: \mathrm{C}, 40.50 ; \mathrm{H}, 2.47 ; \mathrm{N}, 12.88$. Found: C, 40.59; H, 2.38; N, 12.79 .

\section{1. 9. General Procedure for the Synthesis of Compounds 25a-c}

To a solution of compound $1(0.98 \mathrm{~g}, 0.01 \mathrm{~mol})$ in dimethylformamide $(40 \mathrm{~mL})$ containing potassium hydroxide $(0.40 \mathrm{~g}, 0.01 \mathrm{~mol})$ phenylisothiocyanate $(1.30 \mathrm{~g}, 0.01$ mol) was added. The reaction mixture was stirred at room temperature overnight. To the reaction mixture either of 2-bromo-1-phenylethanone ( $2.0 \mathrm{~g}, 0.01 \mathrm{~mol}), 2$-bromo-1(4-chlorophenyl)ethanone $(2.35 \mathrm{~g}, 0.01 \mathrm{~mol})$ or ethyl $\alpha$-chloroacetate $(1.40 \mathrm{~g}, 0.01 \mathrm{~mol})$ was added and the whole reaction mixture was stirred at room temperature overnight. The solid product, so formed in each case, upon pouring onto ice/water containing hydrochloric acid (till $\mathrm{pH} 6$ ) was collected by filtration and crystallised from ethanol.

4-(3,4-Diphenylthiazol-2(3H)-ylidene)-3-methyl-1Hpyrazol-5-(4H)-one (25a). Yield: 85\%; m.p.: 110-112 ${ }^{\circ} \mathrm{C}$; IR $\left(\mathrm{KBr}, \mathrm{cm}^{-1}\right)$ v: $3111(\mathrm{NH}), 3053(\mathrm{CH}$ aromatic), 2999 (CH aliphatic), $1683(\mathrm{C}=\mathrm{O}) ;{ }^{1} \mathrm{H}$ NMR (DMSO- $\left.d_{6}\right)$ $\delta: 2.49\left(\mathrm{~s}, 3 \mathrm{H}, \mathrm{CH}_{3}\right), 7.16$ (s, $1 \mathrm{H}, \mathrm{NH}, \mathrm{D}_{2} \mathrm{O}$ exchangeable), 7.25 (s, 1H, H-thiazole), 7.38-7.72 (m, 10H, Ar-H); ${ }^{13} \mathrm{C}$ NMR (DMSO- $d_{6}, 400 \mathrm{MHz}$ ): 12.5, 91.9, 104.7, 123.8, 126.4, 128.7, 129.1, 129.8, 130.2, 131.5, 138.9, 140.5, 159.8, 176.5; MS (m/z,\%): $333\left(\mathrm{M}^{+}, 20\right)$. Anal. calcd. for $\mathrm{C}_{19} \mathrm{H}_{15} \mathrm{~N}_{3}$ OS: C, 68.45; H, 4.53; N, 12.60. Found: C, $68.29 ; \mathrm{H}, 4.80 ; \mathrm{N}, 12.79$.

4-(3-Phenyl-4-(4-chlorophenyl)thiazol-2(3H)-ylidene)3-methyl-1H-pyrazol-5-(4H)-one (25b). Yield: $82 \%$; m.p.: $182-184{ }^{\circ} \mathrm{C}$; IR $\left(\mathrm{KBr}, \mathrm{cm}^{-1}\right)$ v: $3120(\mathrm{NH}), 3051$ (CH aromatic), 2920 (CH aliphatic), $1699(\mathrm{C}=\mathrm{O}) ;{ }^{1} \mathrm{H}$ NMR (DMSO- $d_{6}$ ) $\delta: 2.49\left(\mathrm{~s}, 3 \mathrm{H}, \mathrm{CH}_{3}\right), 6.98(\mathrm{~s}, 1 \mathrm{H}$, thiazole-H), 7.01 (s, $1 \mathrm{H}, \mathrm{NH}, \mathrm{D}_{2} \mathrm{O}$ exchangeable), 7.23-7.67 (m, 9H, Ar-H); ${ }^{13} \mathrm{C}$ NMR (DMSO- $d_{6}, 400 \mathrm{MHz}$ ): 12.9, 112.0, 120.4, 121.1, 122.6, 124.3, 129.4, 139.1, 140.4, 154.2, 162.2; MS (m/z,\%): $367\left(\mathrm{M}^{+}, 42\right)$. Anal. calcd. for $\mathrm{C}_{19} \mathrm{H}_{14} \mathrm{ClN}_{3} \mathrm{OS}: \mathrm{C}, 62.04 ; \mathrm{H}, 3.84 ; \mathrm{N}, 11.42$. Found: $\mathrm{C}$, $62.18 ; \mathrm{H}, 3.88 ; \mathrm{N}, 11.58$.

4-(4-Hydroxy-3-phenylthiazol-2(3H)-ylidene)-3methyl-1H-pyrazol-5-(4H)-one (25c). Yield:86\%; m.p.: 118-120 ${ }^{\circ} \mathrm{C}$; IR $\left(\mathrm{KBr}, \mathrm{cm}^{-1}\right)$ v: $3396(\mathrm{OH}), 3128(\mathrm{NH})$, $3026(\mathrm{CH}$ aromatic), $2920(\mathrm{CH}$ aliphatic), $1682(\mathrm{C}=\mathrm{O})$; ${ }^{1} \mathrm{H}$ NMR (DMSO- $\left.d_{6}\right) \delta: 2.49\left(\mathrm{~s}, 3 \mathrm{H}, \mathrm{CH}_{3}\right), 5.26(\mathrm{~s}, 1 \mathrm{H}$, $\mathrm{OH}, \mathrm{D}_{2} \mathrm{O}$ exchangeable), $7.31(\mathrm{~s}, 1 \mathrm{H}$, thiazole- $\mathrm{H}), 7.38(\mathrm{~s}$, $1 \mathrm{H}, \mathrm{NH}, \mathrm{D}_{2} \mathrm{O}$ exchangeable $), 7.40-7.49(\mathrm{~m}, 5 \mathrm{H}, \mathrm{Ar}-$ $\mathrm{H}) ;{ }^{13} \mathrm{C}$ NMR (DMSO- $d_{6}, 400 \mathrm{MHz}$ ): 13.6, 112.0, 129.1,
129.2, 134.0, 134.4, 136.0, 164.1, 173.4; MS $(\mathrm{m} / \mathrm{z}, \%): 373$ $\left(\mathrm{M}^{+}, 22\right)$. Anal. calcd. for $\mathrm{C}_{13} \mathrm{H}_{11} \mathrm{~N}_{3} \mathrm{O}_{2} \mathrm{~S}: \mathrm{C}, 57.13 ; \mathrm{H}$, 4.06; N, 15.37. Found: C, 56.99; H, 4.18; N, 15.58 .

\section{2. In vitro Cytotoxic Assay}

Chemicals: Fetal bovine serum (FBS) and L-glutamine were purchased from Gibco Invitrogen Co. (Scotland, UK). RPMI-1640 medium was purchased from Cambrex (New Jersey, USA). Dimethyl sulfoxide (DM$\mathrm{SO}$ ), doxorubicin, penicillin, streptomycin and sulforhodamine B (SRB) were purchased from Sigma Chemical Co. (Saint Louis, USA).

Cell cultures: were obtained from the European Collection of Cell Cultures (ECACC, Salisbury, UK) and human gastric cancer (NUGC), human colon cancer (DLD1), human liver cancer (HA22T and HEPG2), human breast cancer (MCF), nasopharyngeal carcinoma (HONE1) and normal fibroblast cells (WI38) were kindly provided by the National Cancer Institute (NCI, Cairo, Egypt). They grow as monolayer and were routinely maintained in RPMI-1640 medium supplemented with 5\% heat-inactivated FBS, $2 \mathrm{mM}$ glutamine and antibiotics (penicillin $100 \mathrm{U} / \mathrm{mL}$, streptomycin $100 \mathrm{lg} / \mathrm{mL}$ ), at $37^{\circ} \mathrm{C}$ in a humidified atmosphere containing $5 \% \mathrm{CO}_{2}$. Exponentially growing cells were obtained by plating $1.5 \times 10^{5}$ cells / $\mathrm{mL}$ for the six human cancer cell lines followed by $24 \mathrm{~h}$ of incubation. The effect of the vehicle solvent (DM$\mathrm{SO}$ ) on the growth of these cell lines was evaluated in all experiments by exposing untreated control cells to the maximum concentration $(0.5 \%)$ of DMSO used in each assay.

\section{3. Brine Shrimp Lethality Bioassay}

The brine shrimp lethality bioassay was used to predict the toxicity of the synthesized compounds. For the experiment $4 \mathrm{mg}$ of each compound was dissolved in dimethylsulfoxide (DMSO) and solutions of varying concentrations $(10,100,1000 \mathrm{mg} / \mathrm{mL})$ were obtained by the serial dilution technique using simulated seawater. The solutions were then added to the pre-marked vials containing 10 live brine shrimp nauplii in $5 \mathrm{~mL}$ simulated seawater. After $24 \mathrm{~h}$, the vials were inspected using a magnifying glass and the number of survived nauplii in each vial was counted. The mortality endpoint of this bioassay was defined as the absence of controlled forward motion during $30 \mathrm{~s}$ of observation. From this data, the percent of lethality $\mathrm{LC}_{50}$ of the brine shrimp nauplii for each concentration and control was calculated.

\section{Conclusions}

The present research reports the successful synthesis, characterization and evaluation of anticancer activity 
of pyrazolone, pyranopyrazolone, pyrazolopyrimidine and pyrazolothiazole derivatives. Several compounds showed potent cytotoxic effect with $\mathrm{IC}_{50}<100 \mathrm{nM}$. Among these derivatives the pyrazolothiazoles exhibited significant cytotoxic activity. Compound 22a showed the maximum cytotoxicity among the tested compounds. Moreover, it was found to be nontoxic against shrimp larvae ( $A r$ temia salina). Normal fibroblast cells (WI38) were affected to a much lesser extent $\left(\mathrm{IC}_{50}>10,000 \mathrm{nM}\right)$. The obtained results suggest that these compounds may serve as lead chemical entities for further modification in the search of new classes of potential anticancer agents. It could be also concluded that while some of the compounds were not the most potent, their specific activity against particular cell lines makes that of interest for further development as anticancer drugs.

\section{References}

1. X. H. Liu, P. Cui, B. A. Song, P. S. Bhadury, H. L. Zhu, S. F Wang, Bioorg. Med. Chem. 2008, 16, 4075-4082. http://dx.doi.org/10.1016/j.bmc.2008.01.035

2. G. Ouyang, Z. Chen, X. J. Cai, B. A. Song, P. S. Bhadury, S. Yang, L. H. Jin,; W. Xue, D. Y. Hu, S. Zeng, Bioorg. Med. Chem. 2008, 16, 9699-9707.

http://dx.doi.org/10.1016/j.bmc.2008.09.070

3. E. M. N. Abdel-Hafez, G. E. A. A. Rahma, M. A. Aziz, M. F. Radwan, H. H. Farag, Bioorg. Med. Chem. 2009, 17, 38293837.

http://dx.doi.org/10.1016/j.bmc.2009.04.037

4. H. J. Park, K. Lee, S. J. Park, B. Ahn, J. C. Lee, H. Y. Cho, K. I. Lee, Bioorg. Med. Chem. Lett. 2005, 15, 3307-3312. http://dx.doi.org/10.1016/j.bmcl.2005.03.082

5. G. Ouyang, X. J. Cai, Z. Chen, B. A. Song, P. S. Bhadury, S. Yang, L. H. Jin, W. Xue, D. Y. Hu, S. Zeng, J. Agric. Food Chem. 2008, 56, 10160-10167. http://dx.doi.org/10.1021/jf802489e

6. H. Dai, Y. Q. Li, D. Du, X. Qin, X. Zhang, H. B. Yu, J. X. Fang, J. Agric. Food Chem. 2008, 56, 10805-10810. http://dx.doi.org/10.1021/jf802429x

7. S. M. Riyadh, T. A. Farghaly, M. A. Abdallah, M. M. Abdalla, M. R. A. El-Aziz, Eur. J. Med.Chem. 2010, 45, 10421050.

http://dx.doi.org/10.1016/j.ejmech.2009.11.050

8. M. Anzaldi, C. Maccio, M. Mazzei, M. Bertolotto, L. Ottonello, F. Dallegri, A. Balbi, Chem. Biodivers. 2009, 6, 1674 1687.

http://dx.doi.org/10.1002/cbdv.200800354

9. A. El-Shafei, A. A. Fadda, A. M. Khalil, T. A. E. Ameen, F. A. Badria, Bioorg. Med. Chem. 2009, 17, 5096-5105. http://dx.doi.org/10.1016/j.bmc.2009.05.053

10. (a) A. H. Schoenthal, T. C. Chen, F. M. Hofman, S. G. Louie, N. A. Petasis, Expert Opin. Invest. Drugs 2008, 17, 197-208; (b) K. T. Chang, Y. H. Choi, S.-H. Kim, Y. J. Yoon, W. S. Lee, J. Chem. Soc., Perkin Trans. 2002, 207-210. http://dx.doi.org/10.1517/13543784.17.2.197

11. J. Z. Chandanshive, B. F. Bonini, W. Tiznado, C. A. Escobar, J. Caballero, C. Femoni, M. Fochi, M. C. Franchini, Eur. J. Org. Chem. 2011, 25, 4806-4813.

12. J. Z. Chandanshive, B. F. Bonini, D. Gentili, M. Fochi, L. Bernardi, M. C. Franchini, Eur. J. Org. Chem. 2010, 33, 6440-6447 http://dx.doi.org/10.1002/ejoc.201001048

13. S. R. Mandha, S. Siliveri, M. Alla, V. R. Bommena, M. R. Bommineni, S. Balasubramanian, Bioorg. Med. Chem. Lett. 2012, 22, 5272-5278. http://dx.doi.org/10.1016/j.bmcl.2012.06.055

14. E. S. El-Tamany, F. A. El-Shahed, B. H. Mohamed, J. Serb. Chem. Soc. 1999, 64, 9-18.

15. M. E. A. Zaki, H. A. Soliman, O. A. Hiekal, A. E. Rashad, Z. Naturforsch. C. 2006, 61c, 1-5. http://dx.doi.org/10.1515/znc-2006-1-201

16. F. M. Abdelrazek, P. Metz, N. H. Metwally, S. F. El-Mahrouky, Arch. Pharm. 2006, 339, 456-460. http://dx.doi.org/10.1002/ardp.200600057

17. F. M. Abdelrazek, P. Metz, O. Kataeva, A. Jager, S. F. EI-Mahrouky, Arch. Pharm. 2007, 340, 543-548. http://dx.doi.org/10.1002/ardp.200700157

18. N. Foloppe, L. M. Fisher, R. Howes, A. Potter, A. G. S. Robertson, A. E. Surgenor, Bioorg. Med. Chem. 2006, 14, 4792-4802. http://dx.doi.org/10.1016/j.bmc.2006.03.021

19. M. Chauhan, R. Kumar, Bioorg. Med. Chem. 2013, 21, 5657-5668 http://dx.doi.org/10.1016/j.bmc.2013.07.027

20. W. M. Al-Adiwish, M. I. M. Tahir, N. A. A. Siti, S. F. Hashim, N. Ibrahim, W. A. Yaacob, Eur. J. Med. Chem. 2013, 64, 464-476. http://dx.doi.org/10.1016/j.ejmech.2013.04.029

21. M. K. Abd El Hamid, M. D. Mihovilovic, H. B. El-Nassan, Eur. J. Med. Chem. 2012, 57, 323-328. http://dx.doi.org/10.1016/j.ejmech.2012.09.031

22. A. R. Ali, E. R. El-Bendary, M. A. Ghaly; I. A. Shehata, Eur. J. Med. Chem. 2014, 75, 492-500. http://dx.doi.org/10.1016/j.ejmech.2013.12.010

23. J. H. Park, M. I. El-Gamal, Y. S. Lee, C. H. Oh, Eur. J. Med. Chem. 2011, 46, 5769-5777. http://dx.doi.org/10.1016/j.ejmech.2011.08.024

24. A. R. Ali, E. R. El-Bendary, M. A. Ghaly, I. A. Shehata, Eur. J. Med. Chem. 2013, 69, 908-919. http://dx.doi.org/10.1016/j.ejmech.2013.08.021

25. K. M. Dawood, T. M. A. Eldebss, H. S. A. El-Zahabi, M. H. Yousef, P. Metz, Eur. J. Med. Chem. 2013, 70, 740-749. http://dx.doi.org/10.1016/j.ejmech.2013.10.042

26. J. W. Yuan, S. F. Wang, Z. L. Luo, H. Y. Qiu, P. F. Wang, X. Zhang, Y. A. Yang, Y. Yin, F. Zhang, H. L. Zhu, Bioorg. Med. Chem. Lett. 2014, 24, 2324-2328. http://dx.doi.org/10.1016/j.bmcl.2014.03.072

27. R. Y. Guo, Z. M. An, L. P. Mo, S. T. Yang, H. X. Liu, S. X. Wang, Z. H. Zhang, Tetrahedron 2013, 69, 9931-9938. http://dx.doi.org/10.1016/j.tet.2013.09.082 
28. L. Luo, L. Meng, Q. Sun, Z. Ge, R. Li, Tetrahedron Lett. 2014, 55, 259-263. http://dx.doi.org/10.1016/j.tetlet.2013.11.014

29. M. A. Gouda, M. A. Berghot, G. E. Abd El-Ghani, A. M. Khalil, Eur. J. Med. Chem. 2010, 45, 1338-1345. http://dx.doi.org/10.1016/j.ejmech.2009.12.020

30. M. I. Choudhary, W. J. Thomsen, Bioassay Techniques For Drug Development, Harwood Academic Publishers, 2001, p. 9-10.
31. B. Brayn, M. Timothy, S. Tore, General and Applied Toxicology, 2nd Ed., Wiley, 1999, vol. I, pp. 52.

32. M. C. Calleja, G. Persoone, The potential of ecotoxicological tests for the prediction of acute toxicity in man as evaluated on the $1^{\text {st }} 10$ chemicals on the MEIC program. Atla, 1992, 20, 396-405.

\section{Povzetek}

3-Metil-1H-pirazol-5(4H)-on (1) smo uporabili kot izhodišče za razvoj novih spojin, ki delujejo proti raku; raziskali smo tudi odvisnost njihove aktivnosti od strukture (SAR). S spremembami obroča spojine 1, ki smo jih izvedli s pomočjo reakcij z aromatskimi aldehidi in različnimi reagenti smo pripravili ustrezne 6-oksopirano[2,3-c]pirazole 4a-c in njihove aminske analoge 6-aminopirano[2,3-c]pirazole $\mathbf{6 a - c , 8}$; pirazolopirano[2,3-b]piridine 10a-c ter kromenopirano[2,3-c]pirazolone 13,14. Reakcija $1 \mathrm{~s}$ tiosečnino in ustreznimi aromatskimi aldehidi je vodila do nastanka pirazolo[3,4- $d]$ pirimidinskih derivatov 17a-c. Po drugi strani pa smo pirazolo[3,4- $d]$ tiazolne derivate 22a-d pripravili s pomočjo reakcije $1 \mathrm{z}$ žveplom in aril izotiocianati v prisotnosti trietilamina. Reakciji $1 \mathrm{~s}$ fenilizotiocianatom je sledila obdelava z $\alpha$-halokarbonilnimi spojinami 24a-c, kar je vodilo do nastanka tiazolnih derivatov 25a-c. Pripavljenim produktom smo določili citotoksično aktivnost proti različnim rakavim in normalnim celičnim linijam. Za večino spojin se je izkazalo, da imajo opazno antitumorno aktivnost, ob tem pa ne vplivajo na normalne fibroblastne celice. Strupenost najbolj citotoksičnih spojin smo določili tudi s pomočjo testa z morskimi rakci Artemia salina. 